\title{
Drug Discovery of Spinal Muscular Atrophy (SMA) from the Computational Perspective: A Comprehensive Review
}

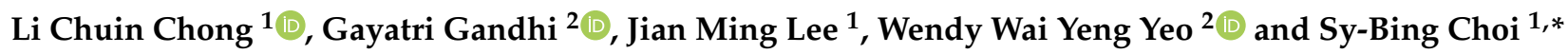 \\ 1 Centre for Bioinformatics, School of Data Sciences, Perdana University, Suite 9.2, 9th Floor, Wisma Chase \\ Perdana, Changkat Semantan, Kuala Lumpur 50490, Malaysia; lichuinchong@gmail.com (L.C.C.); \\ 18110058@perdanauniversity.edu.my (J.M.L.) \\ 2 Perdana University Graduate School of Medicine, Perdana University, Suite 9.2, 9th Floor, Wisma Chase \\ Perdana, Changkat Semantan, Kuala Lumpur 50490, Malaysia; 19120005@perdanauniversity.edu.my (G.G.); \\ wendyyeo@perdanauniversity.edu.my (W.W.Y.Y.) \\ * Correspondence: sybing.choi@perdanauniversity.edu.my
}

Citation: Chong, L.C.; Gandhi, G.; Lee, J.M.; Yeo, W.W.Y.; Choi, S.-B. Drug Discovery of Spinal Muscular Atrophy (SMA) from the Computational Perspective: A Comprehensive Review. Int. J. Mol. Sci. 2021, 22, 8962. https://doi.org/ $10.3390 /$ ijms 22168962

Academic Editor: Giulio Vistoli

Received: 15 January 2021

Accepted: 27 January 2021

Published: 20 August 2021

Publisher's Note: MDPI stays neutral with regard to jurisdictional claims in published maps and institutional affiliations.

Copyright: (C) 2021 by the authors. Licensee MDPI, Basel, Switzerland. This article is an open access article distributed under the terms and conditions of the Creative Commons Attribution (CC BY) license (https:// creativecommons.org/licenses/by/ $4.0 /)$.

\begin{abstract}
Spinal muscular atrophy (SMA), one of the leading inherited causes of child mortality, is a rare neuromuscular disease arising from loss-of-function mutations of the survival motor neuron 1 (SMN1) gene, which encodes the SMN protein. When lacking the SMN protein in neurons, patients suffer from muscle weakness and atrophy, and in the severe cases, respiratory failure and death. Several therapeutic approaches show promise with human testing and three medications have been approved by the U.S. Food and Drug Administration (FDA) to date. Despite the shown promise of these approved therapies, there are some crucial limitations, one of the most important being the cost. The FDA-approved drugs are high-priced and are shortlisted among the most expensive treatments in the world. The price is still far beyond affordable and may serve as a burden for patients. The blooming of the biomedical data and advancement of computational approaches have opened new possibilities for SMA therapeutic development. This article highlights the present status of computationally aided approaches, including in silico drug repurposing, network driven drug discovery as well as artificial intelligence (AI)-assisted drug discovery, and discusses the future prospects.
\end{abstract}

Keywords: drug discovery; drug therapy; spinal muscular atrophy; SMA; neuromuscular disorder; computational aided drug discovery; in silico drug repurposing; artificial intelligence

\section{Introduction}

Spinal muscular atrophy (SMA) is a rare, progressive neuromuscular disease (NMD), arising from loss-of-function mutations of survival motor neuron 1 (SMN1) gene. It is one of the leading inherited causes of infant and early childhood mortality [1,2]. More than 95\% of patients struggle from the homozygous deletion of the SMN1 gene, which is responsible for the encoding of the SMN protein [3]. Consequently, this leads to insufficient SMN protein in neurons, resulting muscle weakness and atrophy, and in severe cases, respiratory failure and death [4]. The severity of SMA, from mild to severe, depends on the presence of the level of SMN protein [5], reflecting an inverse correlation.

Treatment options for SMA are limited and palliative in nature. Even with the remarkable results of approved drugs, the limitations, such as high cost, unknown long-term effects and side effects of the treatments, hinder the success of treating SMA patients. To date, three medications have been approved by the U.S. Food and Drug Administration (FDA) for SMA, which are nusinersen (Spinraza ${ }^{\circledR}$ ) from Biogen, onasemnogene abeparvovec-xioi $\left(\right.$ Zolgensma $^{\circledR}$ ) from Novartis and recently approved risdiplam (Evrysdi ${ }^{\mathrm{TM}}$ ). However, the cost of the former two therapies are astronomical in nature [6-8], while for the latter drug, which is in the early stage from the announcement of FDA approval, the cost has yet to be established. Besides the high cost of the treatment, the challenging drug administration for 
the patients with scoliosis and/or spinal deformity may require sophisticated personnel. As scoliosis is a general symptom of SMA patients, most patients do not acquire the maximal benefits from the current treatments. Several promising therapeutic approaches are currently being developed; some are at different stages of clinical trials. Despite this, the medical cost is still far beyond the affordability of the general populace.

With the advancement of computational approaches, next generation therapeutics may provide a rapid and less expensive access to new treatment. Researchers, nowadays, are gaining the advantage of computational technologies, using genomics, transcriptomics and proteomics approaches to study biological interactions that are crucial for disease pathogenesis and development of new therapies. In addition, the structural analysis on the missense mutations in SMN1 protein served a platform to understand the role of the SMN protein in SMA from the perspective of the molecular structural impact towards drug design. Furthermore, artificial intelligence (AI), machine learning (ML) and/or deep learning (DL) have shifted from hype to hope in the pharmaceutical industry due to increased research and development (R\&D) cost and reduced success and efficiency rate in drug discovery. Owing to the incorporation of genomics and biochemical information, AI serves as an 'Open Target' platform for the prediction of therapeutic targets, which has been successfully applied to amyotrophic lateral sclerosis (ALS), one of the human neurodegenerative diseases [9]. Although there are no drug discovery studies utilizing this technology, this AI-assisted implementation may offer a future hope for SMA patients.

In this review, we provided a brief summary of the biology of SMA disease and discussed the efficacy and efficiency of currently available drugs, both approved and in clinical development. Herein, we also reviewed the past and current research that was carried out with the abovementioned computational approaches and AI-assisted drug discovery approaches in other human neurodegenerative diseases as future perspectives.

\section{Spinal Muscular Atrophy (SMA)}

SMA is a monogenic autosomal recessive genetic disorder characterized by the degeneration of alpha motor neurons ( $\alpha$-MNs) located in the anterior horn of the spinal cord $[10,11]$. The progressive destruction of $\alpha-\mathrm{MNs}$, which is responsible for initiating the muscle contraction, leads to symmetrical muscle weakness and atrophy [12-14]. The primary manifestations of this disease ultimately result in paralysis and often death in severe cases. Proximal muscles, specifically the lower muscles, are affected first, then the upper extremities $[7,15]$. SMA has a unique genetic background, as the change of functional loss in SMA peaks at the onset of the disease followed by progressive worsening condition [16].

SMA is the leading genetic cause of infant mortality globally $[17,18]$ and the second most common fatal autosomal recessive disorder after cystic fibrosis $[19,20]$. It occurs with an estimated pan ethnic incidence of 1 in 6000-10,000 live births and a carrier frequency of 1 in 40-60 [21-23]. As of September 2015, a total of 4526 patients are registered under TREAT-NMD, an international network for the neuromuscular field (https: / / treat-nmd. org/about-the-treat-nmd-network/ (accessed on 1 April 2020)) (Figure 1). The number of SMA registries from Europe continent is generally the highest $(\sim 65.75 \%)$, especially Eastern region with 1028 patients $(\sim 22.71 \%)$. A plethora of studies suggested that there is a difference in incidence and prevalence rate between countries and ethnicities, as well as SMA subtypes [24-26]. A high incidence (13.7 and 17.8 per 100,000) is found from Iceland and Slovakia, countries from the European continent; however, there is a lack of details, such as the number of patients and population size, that may aggravate the interpretation of these findings [25,27,28]. The incidence of African Americans (Black) is low, although the only study concerned a Cuban population [29]. This can be explained by a lower carrier frequency among African Americans and Hispanics, as compared to Caucasians $[24,26,30,31]$. Notably, SMA patients can be classified into five clinical types based on age of onset and level of motor function [32]. 


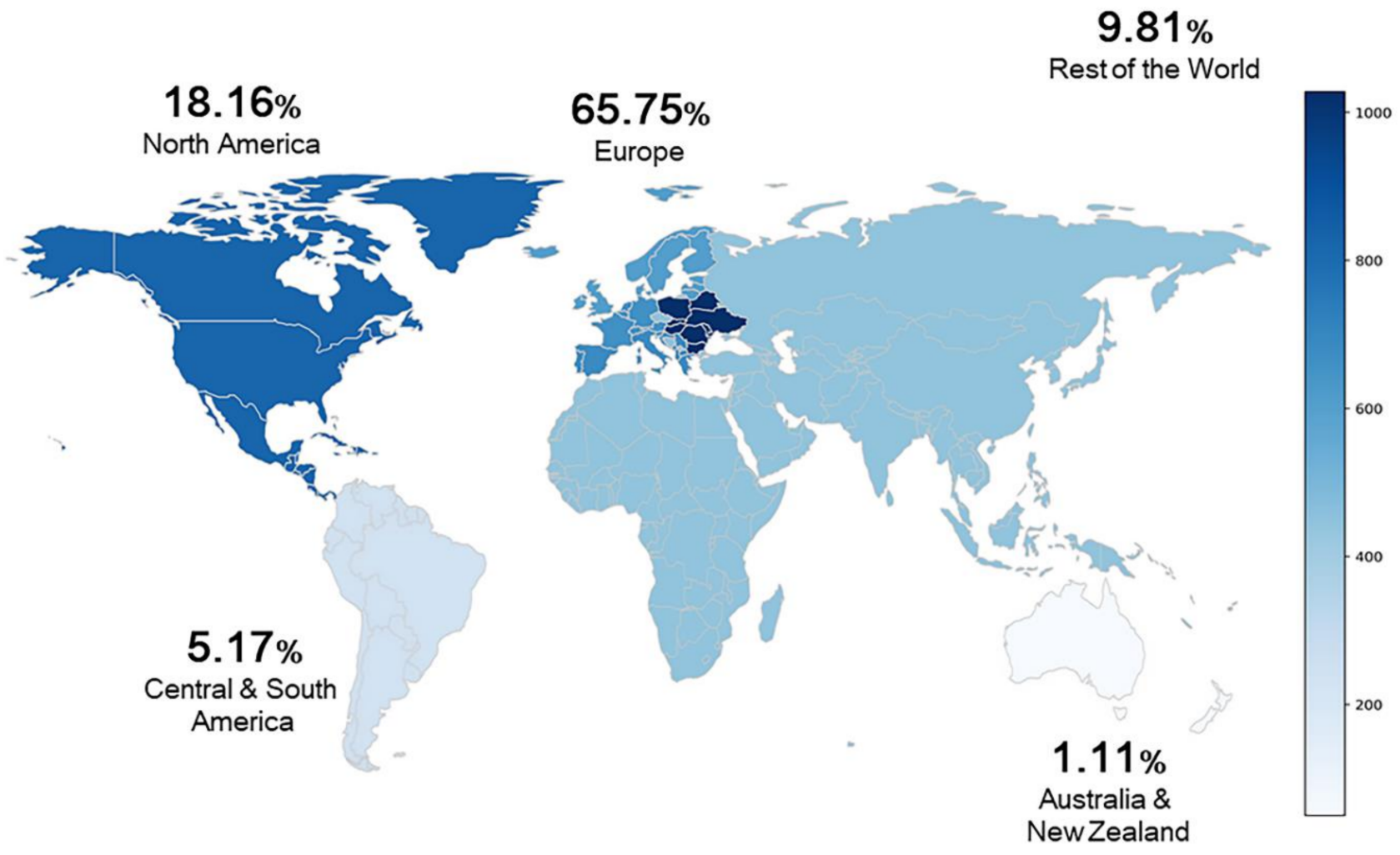

Figure 1. Global distribution of SMA patients who have registered under TREAT-NMD. The number of registries is rounded to two decimal places in percentage and Russia is included in the 'Rest of the World' herein. Data source: TREAT-NMD (https: / / treat-nmd.org/about-the-treat-nmd-network/ (accessed on 1 April 2020)).

\subsection{Disease Etiology}

About $95 \%$ of SMA cases [33,34] are caused by a homologous deletion or mutation of the survival motor neuron 1 (SMN1) gene on chromosome 5q13, which is the blueprint for the SMN protein [3]. The SMN1 is highly conserved and presents as a single copy in the genome of all eukaryotic organisms [35,36]. A normal individual has two forms of the SMN gene, which are telomeric SMN1 and its paralog, centromeric SMN2 [11,37] (Figure 2). Both genes are nearly identical, with only a difference in five base pairs. However, the base pair differences do not alter the amino acid sequence, and they encode the same SMN protein.

The SMN1 gene produces full-length, functional SMN (FL-SMN) protein. A synonymous C-to-T base substitution (c.840C > T) at the position 6 of SMN2 exon 7 disrupts the proper splicing and leads to a majority $(\sim 90 \%)$ of exon 7 -skipped transcript ( $\Delta 7$-transcript) [37-40]. Subsequent translation of such transcript results in a truncated and unstable SMN protein [17,41]. Only $\sim 5-10 \%$ FL-SMN protein will be produced by the SMN2 gene, whereas patients with any form of SMA lack a functioning SMN1 gene and only depend on the SMN2 gene. Therefore, they are in a condition of deficiency with regards to SMN protein production, and thus, they lead to a loss of motor neurons in the spinal cord.

There are five types of SMA, which are known as SMA type 0, I, II, III and IV. The copy number of SMN2 gene modifies the severity of the disease phenotype as a high number of $S M N 2$ copies is related to milder phenotypes [40,42]. For instance, SMA type I patients generally have one or two SMN2 copies, while SMA type III/IV patients have more than four copies [43,44]. Nevertheless, this inverse relationship is not always true, as a few patients with two SMN2 copies showed milder SMA phenotypes, while there have also been patients with three SMN2 copies that have been defined as type I [21,45-47]. Lacking either one SMN gene leads to low levels of SMN protein, though this still allows embryonic development and usually occurs in SMA carriers. Nevertheless, there are no individuals 
with neither SMN genes, which mean homologous loss, as it is hypothesized to be an embryonic lethal condition $[17,48,49]$.

a) Healthy individual

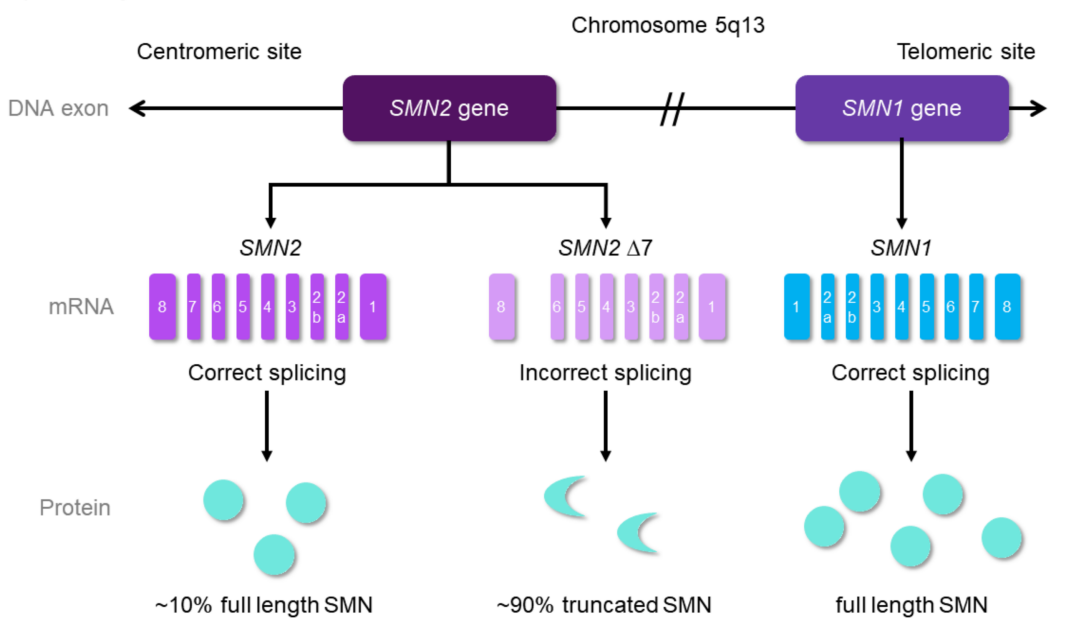

b) SMA patient

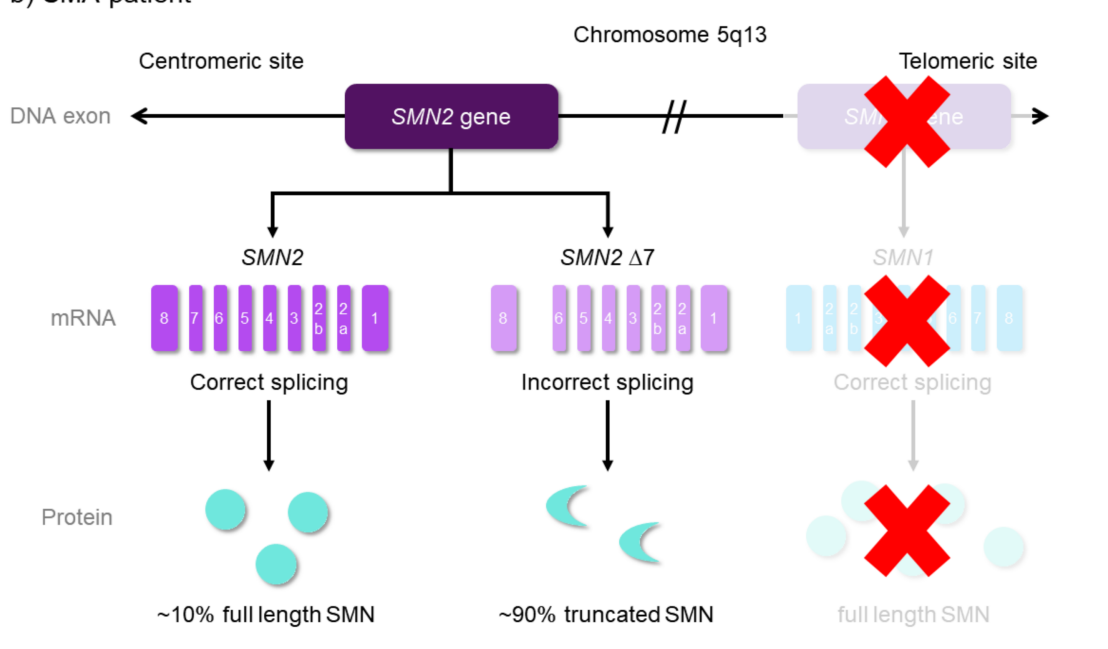

Figure 2. Schematic diagram of human survival motor neuron $(S M N)$ gene expression for both healthy individuals and SMA patients. The telomeric SMN1 and centromeric SMN2 genes are identified specifically in the chromosome 5q13 region (long arm of chromosome 5). The SMN1 gene produces all full length SMN (FL-SMN) protein, while the SMN2 gene produces $~ 10 \%$ FLSMN protein and $\sim 90 \%$ truncated $S M N$ protein $(S M N \Delta 7)$ due to incorrect splicing. (a) In healthy individuals, both SMN genes are present. (b) In SMA patients, the absence of the SMN1 gene, due to mutations, causes no FL-SMN protein production from SMN1 (This condition is indicated as red ' $\mathrm{X}$ '). The production solely depends on the SMN2 gene, resulting insufficient production.

\subsection{Clinical Classification of SMA Subtype}

The variability in severity of SMA was defined into a classification scheme in 1991 and highlighted based on the level of motor function and age of onset. There are only three SMA types in the early scheme [50]. Modifications were subsequently performed by dividing the former third category based on the age of onset, adding a Type IV as adultonset and including a Type 0 for prenatal onset and death within weeks. Figure 3 depicts a classification of five types of SMA that are characterized by the SMN2 copy number. Such a gene is theoretically correlated with the SMN protein level, therefore relating to the onset and severity of different subtypes of SMA. 


\section{Spinal Muscular Atrophy*}

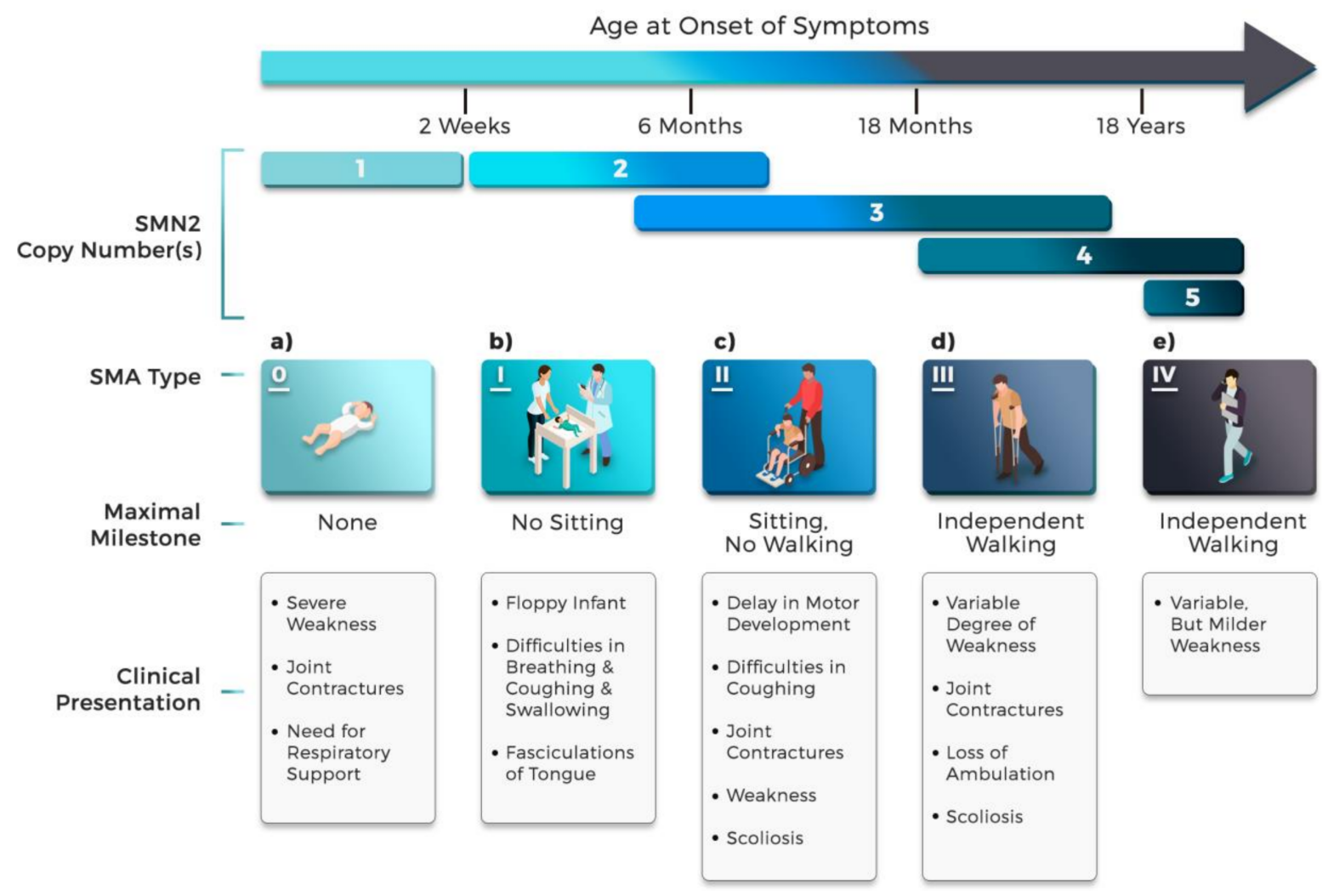

Figure 3. Classification of spinal muscular atrophy (SMA) sub-types. * All SMA patients, regardless of the subtypes, have no functional copies of survival motor neuron 1 (SMN1). SMA can be classified into five types (0-IV) ranging from the most severe form to a milder form. (a) Type 0 is the most severe form and in-utero onset. They normally have limited life expectancy. (b) Type I infants display clinical symptoms at birth or by the age of six months. They never develop the ability to sit and if no intervention is provided results in death by two years. (c) Type II patients are diagnosed within six to 18 months of age and they do develop the ability to sit but they never walk unaided. However, they are able to survive well into adulthood. (d) Type III can be further classified into IIIa (onset between 18 months to three years old) and IIIb (onset between ages of three to 30 years old). They have a normal life expectancy. (e) Type IV is the mildest form and adult-onset. Patients with type IV have a normal life expectancy.

SMA Type 0 (Figure 3a), the rarest yet the most severe form, occurs with minimal presence of the SMN2 gene [2,51]. It is associated with an in utero onset of the affected infants with lesser movement and are often born with arthrogryposis (limited joint deformities/contractures) and hypotonia (extremely weak muscle tone, in particular respiratory and heart muscles), resulting in death before or just after birth. Some of them have respiratory failure, facial diplegia (facial paralysis) and/or heart defects, leading to death during the infancy stage [52-54].

Type I (Figure 3b; Phenotype MIM number from Online Mendelian Inheritance in Man (OMIM; https:/ / www.ncbi.nlm.nih.gov / omim (accessed on 28 August 2020)), MIM 253300), the most common form of SMA ( 45\% of cases) [55], is also known as WerdnigHoffmann disease, with a severe form of muscle weakness evident at birth or within the first few months of life ( six months at most) [2]. Most of the patients, typically present with two or three copies of the SMN2 gene [56], have generalized muscle weakness, including an inability of controlling the movements of the head and inability to sit unaided, among others. Due to weakness of the respiratory muscles, they have breathing distress and increased the risk of aspiration [37,57-59]. Babies have difficulty swallowing and sucking, leading to difficulty with feeding and a failure to thrive [2]. 
Children of SMA Type II (Figure 3c; MIM 253550), which is also known as Dubowitz disease, have a later childhood onset between the ages of six and 18 months [2]. They are able to sit unaided; however, they are not able to stand and walk. The progressive muscle weakness worsens later in life and severely reduces life expectancy. Their symptoms are associated with scoliosis (a spine that curves side-to-side), tremors (involuntary trembling) in their fingers and respiratory muscle weakness $[33,60,61]$. Due to impaired bulbar function, these children develop breathing problems over time [57]. The combination of scoliosis and intercostal muscle weakness leads to respiratory insufficiency and more severely, can be life-threatening.

Approximately 30\% of SMA patients are from Type III (Figure 3d; MIM 253400) [33], referred to as Kugelberg-Welander or Wohlfart-Kugelberg-Welander disease, which has an onset between 18 months to adulthood [37]. Type III is further classified into Type IIIa and IIIb, with onset between 18 months to three years old and between ages of 3 to 30 years old, respectively. Typically, patients develop a variable degree of muscle weakness, resulting in heterogeneous physical symptoms [62]. Although most of them are able to walk independently, some present with progressive proximal weakness and lose ambulation after early childhood, and the disease is usually associated with foot deformity, difficulty of climbing stairs and muscle cramps $[2,33,63]$.

Similar to the characteristics of SMA Type III [64], patients of SMA Type IV (Figure 3e; MIM 271150) have a late onset, namely in adulthood, usually present at the age of 30 and above. This type accounts for less than 5\% [33] of overall SMA cases, and hence, is considered as a mild form of SMA. Comparatively, they might have minor disabilities; nonetheless, they are able to achieve motor milestones and have normal life expectancy [2,62].

\subsection{SMN Protein}

Mutation events of the SMN1 gene that encodes the SMN protein is predominantly linked to SMA disease [65]. Understanding the molecular structural of SMN protein is important and helpful in molecular pathogenesis of SMA. However, as of January 2021, there is still no FL-SMN protein structure in Protein Data Bank (PDB; https:/ / www.rcsb. org/ (accessed on 29 January 2021)) and only have SMN-related structures. The SMN, a 38-kDa protein, is ubiquitously expressed in both nucleus and cytoplasm [66] in particular, having a high concentration in motor neurons of the spinal cord and relatively less in lymphocytes and fibroblasts [67]. Human SMN protein is coded by eight exons [68] and it consists of 294 amino acids and harbors several functional domains, including a basic/lysine (K)-rich region, a Tudor domain, a proline (P)-rich region and a tyrosineglycine rich (YG)-box (Figure 4). Those functional domains are highly conserved from yeast to human and play important roles in the motor system as well as intracellular processes [69].

The Gemin2 binding domain (Ge2BD), coded by exon 2 and located near the Nterminus, is highly conserved among SMN-containing eukaryotes, suggesting the important role of SMN-Gemin2 interaction [70,71]. Gemin2 is a core protein that functions in the formation of SMN complex and also aids in the spliceosomal small nuclear ribonucleoprotein (snRNP) assembly via the stabilization of the SMN complex [72]. The p53, a tumor suppressor protein and also transcription regulator, interacts with the domain coded by exon 2 [73]. The association of p53 with SMN suggests the likelihood for apoptosis to occur. However, when this interaction is reduced, this could lead to death of motor neurons, as shown in SMA.

A central Tudor domain, coded by exon 3 of SMN, facilitates the protein-protein interactions [74]. The domain, which is usually found in RNA-associated proteins, recognizes symmetric dimethylarginine (sDMA) modifications in arginine/glycine rich regions (RG domains) of proteins, including Sm proteins (B, D1 and D3) [70,75-77]. Interestingly, SMAcausing mutations of this domain impair sDMA peptide binding [70]. The proline-rich region, coded by exon 4 to 6 , interacts with prophilin, a key protein in controlling the actin dynamics in the cells $[78,79]$. 


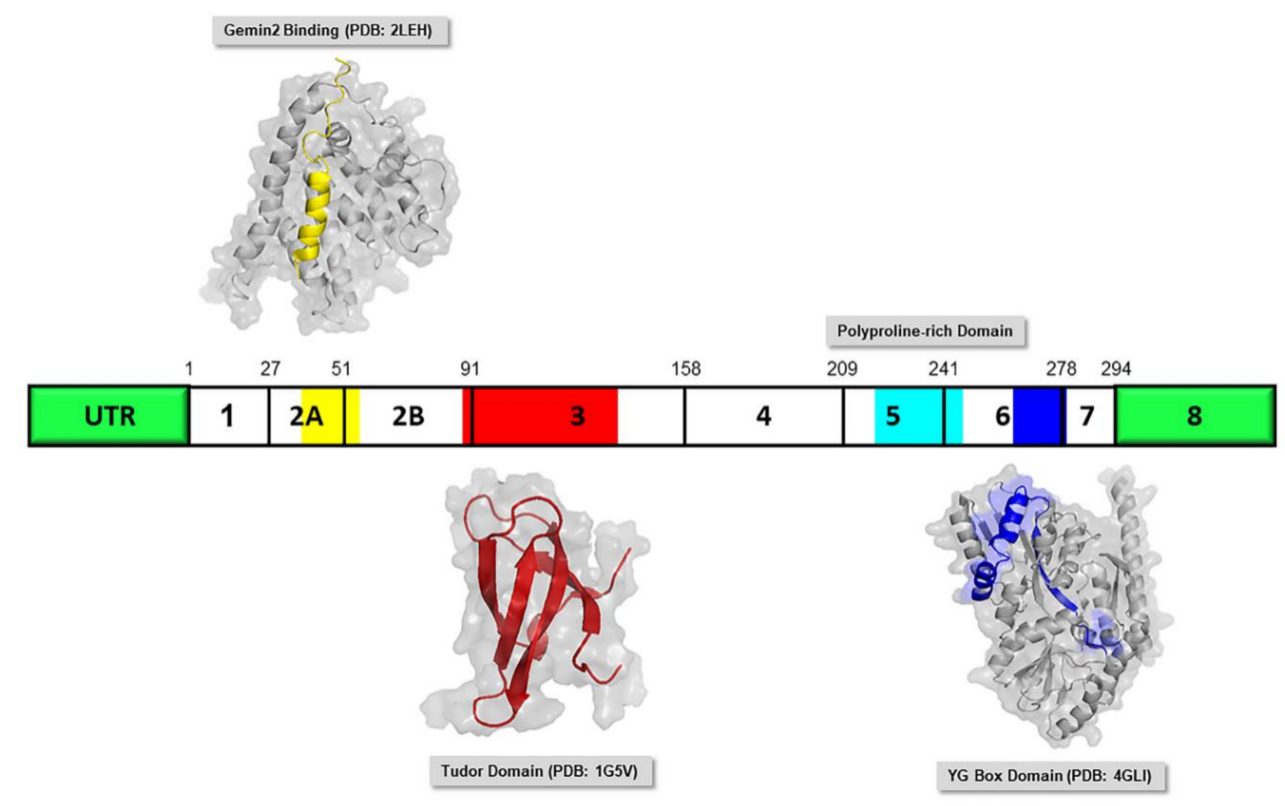

Figure 4. Diagrammatic representation of the full length SMN (FL-SMN) protein with its respective available protein structure. The number of exons is indicated within the boxes of SMN protein diagram with the number of the last amino acid residue of each exon, indicated above. The PDB structure of the domains are illustrated in the same color that overlaid in the SMN protein diagram indicating the location of the respective domains (Gemin2 Binding: yellow; Tudor Domain: red; Polyproline-rich Domain: cyan; YG Box Domain: blue). Abbreviation: UTR, untranslated region.

A most conserved segment near the C-terminus [71], referred to as the 'YG-box,' is responsible for oligomerization, which is crucial for the function of SMN and interaction between SMN with Gemins and Sm proteins. It is also involved in the interaction with Gemin3 (a dead-box helicase) [80], ZPR1 (a zinc-finger protein) [81] and SIN3A (a transcription co-repressor) [82].

Given the SMN protein's critical role in the biogenesis of snRNPs, SMA patients fully depend on SMN2 gene to compensate the loss of the SMN1 gene for the production of the SMN protein. However, a relatively low amount of functional SMN protein is produced while the translated product of aberrant splicing event, termed SMN $\Delta 7$ (only consists of 282 residues; Figure 5), is unstable and rapidly degrades [83]. The half-life of a functional $\mathrm{SMN}$ is $>8 \mathrm{~h}$, while SMN $\Delta 7$ is about $3 \mathrm{~h}$. A study suggested that the addition of a fouramino acids motif, EMLA, and a conserved tyrosine/glycine rich motif, YG region, at the C-terminal, reduce the stability of $\mathrm{SMN} \Delta 7[71,83]$. EMLA serves as a degradation signal for $\Delta 7$-transcript, is coded by exon 8 , while the YG region is coded by exon 6 and 7 [71]. Interestingly, the future deletion of EMLA and YG region from SMN $\Delta 7$ alone, termed as SMN $\triangle 7 \Delta$ EMLA and SMN $\Delta 7 \Delta \mathrm{YG}$, respectively (Figure 5), show the increment of the half-life [83]. 


\begin{tabular}{|c|c|c|c|c|c|c|c|c|c|c|}
\hline \multirow[b]{2}{*}{ FL-SMN } & \multicolumn{3}{|c|}{$\begin{array}{lll}1 & 27 & 51 \\
\end{array}$} & \multicolumn{2}{|c|}{91} & 158 & \multicolumn{2}{|c|}{241} & \multicolumn{2}{|c|}{$\begin{array}{l}78 \quad 294 \\
\end{array}$} \\
\hline & UTR & 1 & $2 A$ & 2B & 3 & 4 & 5 & 6 & 7 & 8 \\
\hline
\end{tabular}

SMN $\triangle 7$

\begin{tabular}{|l|l|l|l|l|l|l|l|l|l|}
\hline UTR & $\mathbf{1}$ & $\mathbf{2 A}$ & $\mathbf{2 B}$ & $\mathbf{3}$ & $\mathbf{4}$ & $\mathbf{5}$ & $\mathbf{6}$ & $\mathbf{4}$ \\
\hline
\end{tabular}

SMN $\triangle 7 \triangle E M L A$

\begin{tabular}{|c|c|c|c|c|c|c|c|c|}
\hline & & 5 & & & & & & \\
\hline UTR & 1 & $2 A$ & 2B & 3 & 4 & 5 & 6 & 8 \\
\hline
\end{tabular}

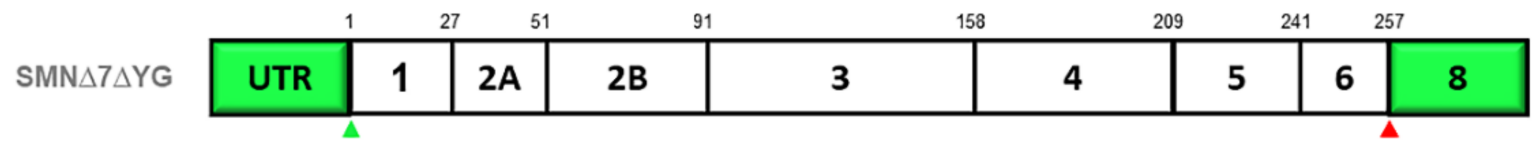

Figure 5. Schematic diagram of transcripts generated from SMN with a series of deletions. The name of the transcript is shown on the left, which indicates the deleted region. For instance, $\Delta 7$ refers to the deletion of exon 7 . The start and stop codons are depicted in green and red triangle icons, respectively. The YG region, a conserved tyrosine/glycine rich motif, in exon 6 and 7 is indicated by the blue box while EMLA, a four-amino acids motif that replaced the 16-amino acids of exon 7 , is indicated with an arrow. Abbreviation: UTR, untranslated region.

\section{Current Drug of SMA}

It is well known that the disease severity is related to the SMN protein levels, and thus, increasing SMN production has been a major SMA drug discovery strategy [84]. Multiple mechanisms have been targeted to drive higher expression of the full length SMN protein, either from the SMN2 gene or from the exogenously restored SMN1 gene [35,62]. The SMN protein was suggested to play a crucial role in neurons and muscle [85-87]; hence, SMN-independent therapies that provide neuroprotection or slowing down or halting the events due to the effects of SMN depletion could be an alternative for SMA [88].

\subsection{Current Drug-Early Success}

Out of 1167 US Food and Drug Administration (FDA)-approved drugs (as of March 2020), there are only three drugs approved for the treatment of SMA, which are nusinersen, onasemnogene abeparvovec and risdiplam.

Nusinersen (Trade name: Spinraza ${ }^{\circledR}$ ) was the first therapy approved in late 2016 by the FDA to treat this rare NMD [89]. Nusinersen, a modified 2'-O-methoxyethyl phosphorothioate antisense oligonucleotide (ASO), effectively modulates the splicing of SMN transcripts [6,90-92]. The drug is directly administered to the central nervous system (CNS) via intrathecal injection to modify the splicing process of SMN2 pre-mRNA by promoting exon 7 retention, resulting in the enhancement of the FL-SMN protein expression level $[90,93]$ (Figure 6). Hua et al. (2010) highlighted that nusinersen provides phenotypic and pathologic benefit in the animal models, both mild and severe SMA through direct injection into CNS. This was in agreement with Passini et al. (2011), who worked on improving the efficacy of ASO [94]. However, due to the inability of the transverse of the blood-brain barrier, it is applied via injection into the spinal canal for SMA therapeutic application [95].The intrathecal route allows the direct delivery of drugs to CNS by circumventing the blood-brain barrier [96]. The recommended dose for nusinersen is $12 \mathrm{mg}$ [6]. Results on the trials on nusinersen suggested that some patients can even achieve certain milestones that have been lost without treatment, including sitting, standing and walking. This treatment has been suggested to be given early in the course of the disease and worked efficiently among the patients with SMA type I, II and III [97]. The 
major drawback of this treatment is that the patient has an increased risk of getting upper and lower respiratory tract infections and constipation [98].

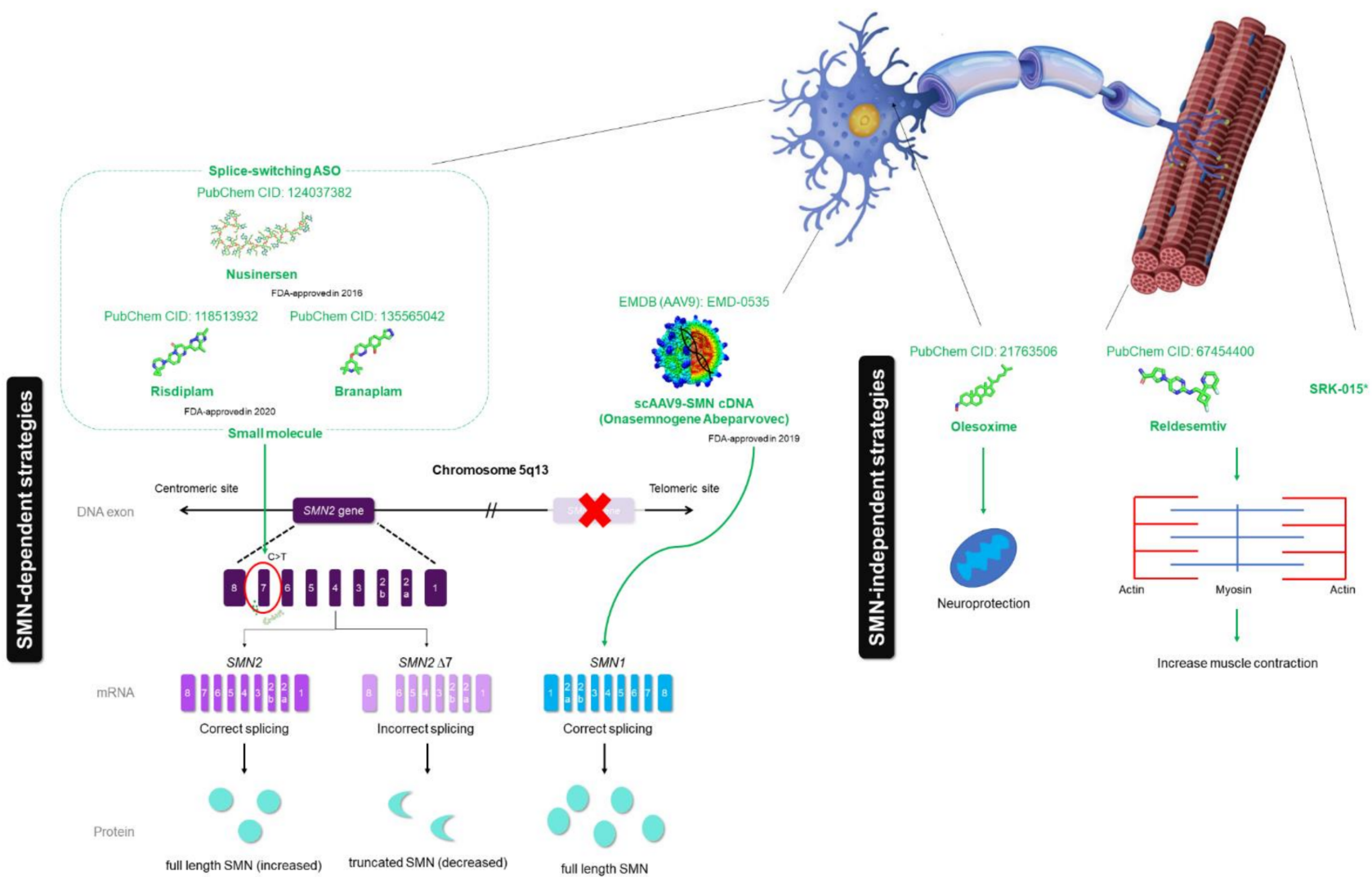

Figure 6. Therapeutic mechanism of SMA drugs, including three FDA-approved drugs (nusinersen, onasemnogene abeparvovec and the recent FDA-approved drug risdiplam) and drugs that are in clinical trials (branaplam, olesoxime, reldesemtiv and SRK-015). Nusinersen (PubChem CID: 124037382), a synthetic antisense oligonucleotide (ASO), is designed to hybridize intronic splicing silencer N1 (ISS-N1), which is heterogenous nuclear ribonucleoprotein (hnRNP) A1-dependent, to facilitate accurate splicing of SMN2 transcripts. Onasemnogene abeparvovec (no available structure) is a gene therapy that targets the SMN1 gene replacement using adenovirus vector AAV9 (EMDB: EMD-0535). Risdiplam (PubChem CID: 118513932) and branaplam (PubChem CID: 135565042) are small molecules that have the same mechanism of action as nusinersen. The red ' $X$ ' mark represents the deleted SMN1 gene. Other than SMN-dependent drugs, olesoxime (PubChem CID: 21763506) acts as neuroprotective compound, while reldesemtiv (PubChem CID: 67454400) and SRK-015 act as a fast skeletal muscle troponin activator (FSTA) and myostatin inhibitor, respectively, to increase the muscle contraction.

In 2019, onasemnogene abeparvovec (onasemnogene abeparvovec-xioi; formerly AVXS-101), under the trade name Zolgensma ${ }^{\circledR}$ has been approved by FDA as the second disease modifying SMA treatment for patients aged up to 2 years old with SMA type I [99]. It comprises the capsid of adeno-associated virus 9 (AAV9), delivering complementary DNA (cDNA), which codes for the SMN protein, to its target motor neurons [100,101]. With a single, one-time intravenous (IV) administration, AVV9 crosses the blood-brain barrier and delivers a working copy of the SMN1 gene able to reach patients' cells, allowing the production of the SMN protein (Figure 6). Additionally, the SMN1 transgene, along with the synthetic promoter that consists of the AVV9, plays an important role to sustain SMN protein production in the long term. Given its effectiveness in resolving the SMA molecular defect, it adversely affects the liver by increasing the level of serum aminotransferase, a liver enzyme $[7,101,102]$. However, elevated liver enzymes can be controlled by using prednisone [16]. Hence, patients need to be monitored for their liver function at least three months after administration [7]. 
Recently (as of 7 August 2020), risdiplam (Trade name: Evrysdi ${ }^{\mathrm{TM}}$ ) was approved by the FDA as the first oral drug for SMA patients [103]. Risdiplam, formerly known as RG7916, is an investigative drug being developed by Hoffmann-La Roche in collaboration with PTC Therapeutics and SMA Foundation to treat all types of SMA [62]. Similarly to nusinersen, it acts as a SMN2 splicing modulator (Figure 6) and improves the efficiency of the transcription of the SMN2 gene, thus increasing the systemic SMN protein concentration. Ratni et al. (2018) demonstrated the two-fold increment in SMN protein concentration after 12 weeks of therapy in patients [104]. However, it may cause some side effects, including fever, diarrhea, rash, upper respiratory tract infections, pneumonia, constipation and vomiting according to the respective clinical trial (FIREFISH for infants aged 2 to 7 months and SUNFISH for children and adults aged 2 to 25 years) [103].

Despite the discovery of promising therapeutic strategies, the limitations, including the treatment viability (in the case of nusinersen), long-term effects, side effects and cost, among others, are highlighted. As the drugs need to pass through the blood-brain barrier (BBB), nusinersen must be administrated locally through an intrathecal injection. This route of administration is challenging and requires sophisticated personnel and technique, such as image-guided technique, particularly for patients with scoliosis and/or spinal deformity [105]. Moreover, elevated costs of nusinersen ( USD $\$ 125,000$ per injection) associated with screening and subsequent treatment ( USD \$750,000 in the first year and $\sim \mathrm{USD} \$ 375,000$ annually for subsequent year) place this drug among the most expensive drugs $[6,106]$. For the latest approved gene therapy, onasemnogene abeparvovec costs $\sim$ USD \$2.125 million per injection, although only a single treatment is required for each SMA type I patient [107], while the cost of risdiplam (the most recent FDA-approved drug) is yet unknow. Additionally, as all are relatively new therapies, there are no longitudinal studies for long-term effects, although there is a plethora of studies for side effects. Therefore, a more cost-effective drug with an alternative route of administration is required for this devastating SMA.

\subsection{Existing Drug-Clinical Trial Stage}

Several therapies (Table 1) aiming to increase SMN protein level have been studied with a different approach, which is small molecule-based. With the promising preclinical results, risdiplam and branaplam are currently being tested in clinical trials. Risdiplam (Table 1), the recent FDA-approved drug, is still being evaluated in two clinical trial programs, which are JEWELFISH (ClinicalTrials.gov identifier: NCT03032172) and RAINBOWFISH (ClinicalTrials.gov identifier: NCT03779334) [108]. The former trial is aiming for SMA patients aged 6 months to 60 years old, while the latter trial is for those infants from birth to six weeks who are asymptomatic but genetically diagnosed with SMA.

Branaplam (Table 1), developed by Novartis Pharmaceuticals, also known as LMI070 and NVS-SM1, acts similarly to risdiplam to improve the SMN protein concentration by correcting the splicing defect in human SMN2 gene [62,109]. As the clinical trial phase II (ClinicalTrials.gov identifier: NCT02268552) only began in July 2019, there is a lack of information regarding this therapy.

Although there are some promising clinical and preclinical results from ASOs, small molecules and gene therapies on SMN2, there are still some negative impacts on efficacy [100]. Hence, with the specific function of SMN protein by involving in the neuronal actin cytoskeleton [110], expanding the repertoire of targets, for example drugs to improve neuromuscular function, is an alternative for SMA drug discovery to complement the efficiency. 
Table 1. Therapeutic approaches in spinal muscular atrophy: clinical trial stage.

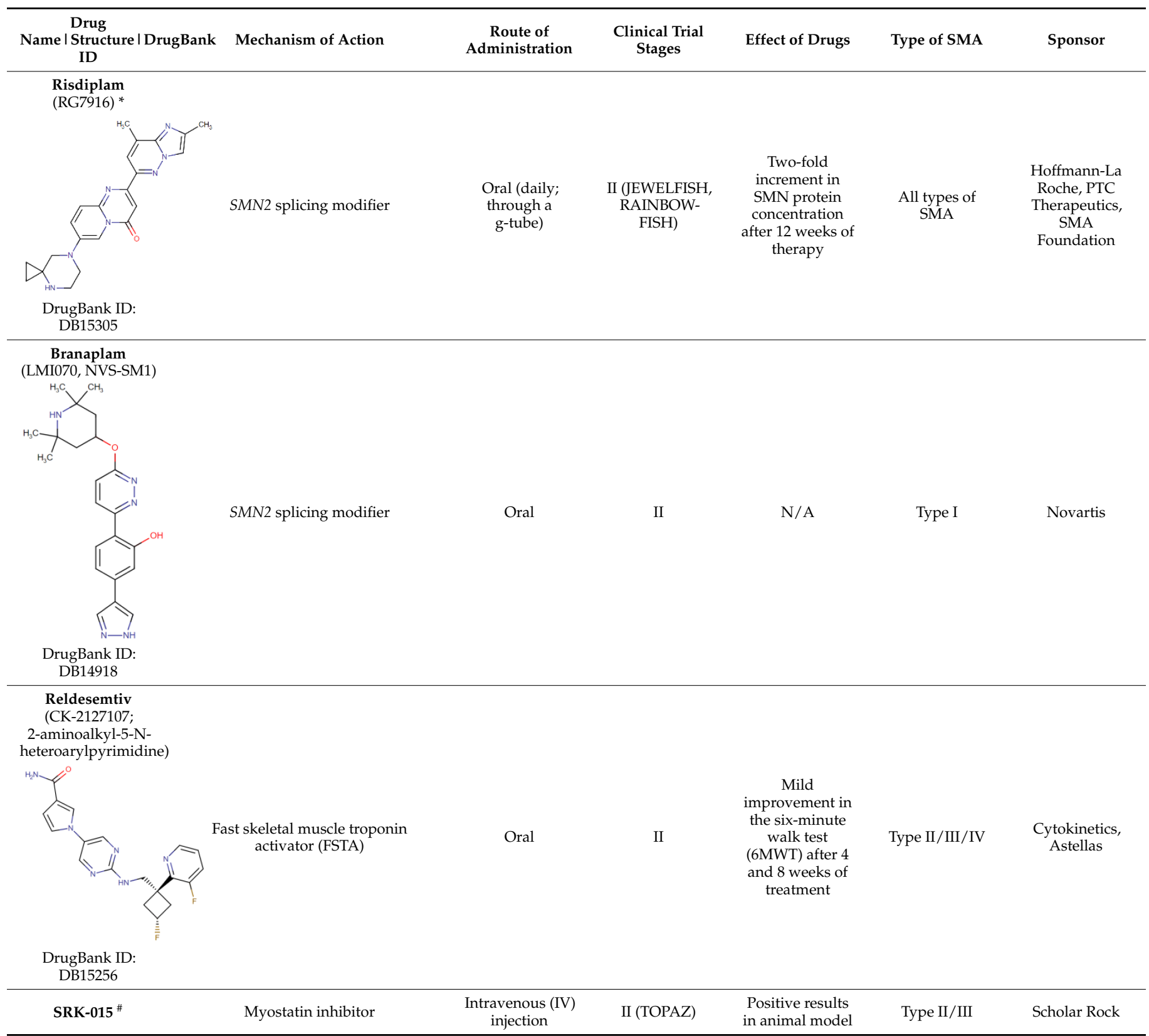

${ }^{*}$ Have been recently approved by FDA (as of August 2020) for the patients aged from 2 years old and above; however, it is still under evaluation for a broad range of patients. " No information of structure and DrugBank ID.

In collaboration with Astellas, reldesemtiv (Table 1), formerly known as CK-2127107, is being developed by Cytokinetics. It acts as a troponin stimulant that may improve muscle mass and function in SMA and amyotrophic lateral sclerosis (ALS) patients [62,111,112]. This drug slows down the release of calcium from the regulatory troponin complex of fast skeletal muscle fibers. The sarcomere is then sensitized to calcium, leading to improved skeletal muscle contractility and physical performance in a human cohort [113]. Notably, the interim analyses of SMA patients showed mild improvement for six-minute walk test (6MWT) and maximal expiratory pressure (MEP) [23]. With the positive result of Phase I, reldesemtiv is now under investigation in Phase II clinical trial (ClinicalTrials.gov identifier: NCT02644668) [111].

Developed by Scholar Rock, SRK-015 (Table 1) is a biological monoclonal antibody against myostatin [23,62]. Myostatin, primarily found in skeletal muscle cells in latent form, plays an important role in inhibiting the muscle growth and maintaining the skeletal 
muscle mass [114]. With this mechanism of action of SRK-015, muscle tissue of SMA patients is plausible to convert into active form. The positive result in Phase I (well dose tolerance up to $30 \mathrm{mg} / \mathrm{kg}$ ) provides opportunities for patients with SMA Type II and III for Phase II (TOPAZ; ClinicalTrials.gov identifier: NCT03921528).

\section{Computer-Aided Drug Design (CADD)-The Open Window of Therapeutic Agents}

With technological advances in the areas of molecular structure characterization, computational science and molecular biology, CADD is a promising avenue to facilitate the discovery, design and optimization of potential therapeutic agents in the era of big data. Not only does it reduce the time for drug discovery, CADD plays a prominent role in reducing the quantity of testing molecules in vitro or in vivo $[115,116]$. By predicting the numerous small molecules, either natural or synthetic compounds, that bind favorably to the target macromolecules, the number of trial experiments can be minimized.

Of neurological disorders, the discovery of efficient CNS drugs is more challenging as compared with other diseases [117]. There are several challenges, in general, throughout the drug discovery process. The most notable obstacle, in the process of lead optimization, is due to the presence of the blood-brain barrier that restricts the flow of molecules to the brain. Nonetheless, it is possible to overcome and predict biological activity, pharmacokinetics (absorption, distribution, metabolism and extraction; ADME) as well as toxicity with the advent of more sophisticated computational approach such as the high throughput screening (HTS) method and CNS multiparameter optimization algorithm $[117,118]$.

Approved or investigated drugs, either SMN-dependent or SMN-independent, were identified with an impressive preclinical or clinical effect; however, none of them are able to cure the disease alone. Hence, this invokes the compelling motivation to implement a CADD approach to speed up the development of the SMA drug-in silico drug repurposing, network-driven drug discovery (NDD) and artificial intelligence (AI)-assisted drug discovery (AID).

\subsection{In Silico Drug Repurposing}

Drug repurposing, also known as drug repositioning, is one of the emerging potential approaches to circumvent the cost and time required for the development of an efficacious treatment $[116,119]$. It is defined as a process of identifying new therapeutic indications for an approved drug. Recently, with the encouragement of fast track marketing authorization procedure (FDA approvals), this approach has been widely used for rare diseases [119], including SMA [120], because it offers several benefits over the classical de novo development process of drugs. The approved drug compounds, in essence, have passed safety efficacy, allowing an omission of Phase I clinical trials [120,121].

Several studies have successfully repurposed FDA-approved drugs for SMA treatment and showed plausible in vitro activities, such as enhancing the SMN2 promoter activity, modulating SMN2 splicing and stabilizing SMN2 mRNA or SMN protein [62,112,120]. Histone deacetylase inhibitors (HDAC), including sodium butyrate, phenylbutyrate and valproic acid (VPA), among others, to date, have been explored with SMN2 promoter activity [112,122-125]. They have demonstrated an increase of SMN protein levels in patient-derived cells as well as in animal models. HDAC induces the alteration in the chromatin structure into a tight-coiled transcriptionally-repressed region of chromatin, thereby activating the gene expression $[112,126]$. The ability to reverse the cell transcription held some promise on SMA. Notably, a plethora of studies demonstrated that the most promising HDAC, VPA, increases two- to four-fold of full length SMN protein in patientderived fibroblast cell lines [125,127]. A recent study by Pagliarini et al. (2020) suggests that the combination of HDAC and nusinersen exerted synergistic effect in enhancing the expression of SMN2-derived FL-SMN protein [128]. This may reduce the frequency of nusinersen administration, leading to a reduction of the financial burden for SMA patients.

In essence, SMN-independent drugs are centered on neuroprotective and muscle enhancing approaches. Neuroprotective drugs aim to improve the motor neuron func- 
tion while muscle enhancers aim to increase the muscle mass and enhance the muscle contractibility [111]. In referencing to the localization of the SMN protein in neuronal cells, neuroprotective drugs for other CNS diseases could be a better option to reposition for preventing and/or delaying motor neuron death in SMA. Approved neuroprotective drugs, such as riluzole, hydroxyurea and rasalgiline, which modulate regulatory pathways in CNS, may be an option for SMA therapy [62,112,120]. For instance, riluzole, an approved drug for ALS, exhibits neuroprotective effects through glutamate reduction. The interim analyses in SMA animal model showed stabilization of neuromuscular junctions; however, it failed to yield the promising clinical trial result [111]. This may be due to poor pharmacokinetics properties, leading to poor long-term efficacy [129]. Despite the limited successes of riluzole, repurposing FDA-approved drugs for CNS disease, including rasalgiline, is an interesting avenue for SMA.

Given the potential of the drug repurposing approach, with the combination of publicly available databases and computational methods, the in silico-based approach may provide benefits, in terms of time and cost, towards the drug discovery process by narrowing down the top hits through in silico validations [130]. Public repositories for relevant experimental and biological data, including chemical structures, gene expression, drug disease association, phenotypic traits, side effects and more, are treasure troves for in silico drug repurposing. Few important databases that are widely used in drug repurposing studies are collectively outlined in Table 2 with corresponding URLs. Owing to the wealth of multi-omics data, different methods have been adopted in drug repurposing, which can be divided into two major categories: (i) drug-oriented and (ii) disease/therapyoriented [131].

Drug-oriented drug repurposing strategies require the knowledge of cheminformatics and bioinformatics as foundation, including drug information, chemical structures of drug and target, drug-target network, signaling or metabolic pathway and genomic information. Information on chemical structure of small molecule compounds can be easily retrieved from the widely used chemical structure database, such as PubChem [155], ChEMBL [137] and DrugBank [145], among others. The RCSB Protein Data Bank (PDB) [156] is the primary database for the three-dimensional (3D) structure of protein target. This 3Dstructure information is crucial for structure-based screening, which aims to reveal how a ligand binds to the protein target with the aid of molecular docking. Alternatively, a structure information can be codified into line notation-Simplified Molecular Input Line Entry System (SMILES) [186] and International Chemical Identifier (InChl) [187] that can be easily analyzed algorithmically. Moreover, the chemical structure similarity approach between ligands suggests two molecules that have similar structure are likely have similar bioactivities [188]. This can be measured using chemical structure fingerprints, either two- (2D) or three-dimensional (3D), or binary, with a distance metric such as Euclidean, Manhattan and Mahalanobis (in the case of non-binary chemical fingerprints) as well as Tanimoto coefficient (Tc; in the case of binary chemical fingerprints) $[189,190]$. Incorporated with drug-target interactions (DTIs), the chemical structure similarity between drug compounds and ligand targets may reveal unforeseen associations. DTIs, which are available in BindingDB [133], ChEMBL [137] and DrugBank [145], among others, can simply indicate the presence or absence of an interaction. This binary-level information is useful to employ in pharmacophore modeling, and few models have been recently developed [191-193]. Other than chemical structure data resources, genomics data that are available from the National Center for Biotechnology Information (NCBI) GenBank, Gene Expression Omnibus (GEO) [172], Single Nucleotide Polymorphism database (dbSNP) [175] and Sequence Read Archive (SRA) [174] are also important to understand the disease and drug mechanism of actions in order to provide insight on the discovery of new uses for existing drugs. 
Table 2. List of databases that widely used for the in silico drug repurposing studies.

\begin{tabular}{|c|c|c|c|}
\hline Category & Database & URL & Reference \\
\hline \multirow{24}{*}{$\begin{array}{l}\text { Drug and } \\
\text { target database }\end{array}$} & Binding Database (BindingDB) & $\begin{array}{c}\text { https://www.bindingdb.org/bind/index.jsp (accessed on } 29 \\
\text { December 2020) }\end{array}$ & {$[132,133]$} \\
\hline & $\begin{array}{l}\text { Biological General Repository for } \\
\text { Interaction Datasets (BioGRID) }\end{array}$ & https://thebiogrid.org/ (accessed on 29 December 2020) & {$[134,135]$} \\
\hline & ChEMBL & $\begin{array}{l}\text { https://www.ebi.ac.uk/chembl/ (accessed on } 29 \\
\text { December 2020) }\end{array}$ & {$[136,137]$} \\
\hline & ChemDB & http://chemdb.ics.uci.edu/ (accessed on 29 December 2020) & [138] \\
\hline & ChemSpider & http://www.chemspider.com/ (accessed on 29 December 2020) & [139] \\
\hline & Connectivity Map (CMap) & $\begin{array}{c}\text { https:/ / portals.broadinstitute.org/cmap / (accessed on } 29 \\
\text { December 2020) }\end{array}$ & {$[140,141]$} \\
\hline & Database of Interacting Proteins (DIP) & $\begin{array}{c}\text { https:/ / dip.doe-mbi.ucla.edu/dip /Main.cgi (accessed on } 29 \\
\text { December 2020) }\end{array}$ & {$[142,143]$} \\
\hline & Drug Repurposing Hub & $\begin{array}{l}\text { https://clue.io/repurposing (accessed on } 29 \text { December 2020) } \\
\text { (accessed on } 29 \text { December 2020) }\end{array}$ & [144] \\
\hline & DrugBank & http://www.drugbank.ca/ (accessed on 29 December 2020) & [145] \\
\hline & DrugCentral & http:/ /drugcentral.org (accessed on 29 December 2020) & [146] \\
\hline & $\begin{array}{c}\text { Exascale Compound Activity Prediction } \\
\text { Engine (ExCAPE-DB) }\end{array}$ & $\begin{array}{c}\text { https://solr.ideaconsult.net/search/excape/ (accessed on } 29 \\
\text { December 2020) }\end{array}$ & [147] \\
\hline & GPS-Prot & http://gpsprot.org/ (accessed on 29 December 2020) & [148] \\
\hline & $\begin{array}{l}\text { Human Protein Reference Database } \\
\text { (HPRD) }\end{array}$ & http:/ /www.hprd.org/ (accessed on 29 December 2020) & {$[149,150]$} \\
\hline & $\begin{array}{l}\text { Library of Integrated Network-based } \\
\text { Cellular Signatures (LINCS) }\end{array}$ & $\begin{array}{c}\text { https:/ /lincs.hms.harvard.edu/db / (accessed on } 29 \\
\text { December 2020) }\end{array}$ & [151] \\
\hline & Molecular INTeraction database (MINT) & https://mint.bio.uniroma2.it/ (accessed on 29 December 2020) & {$[152,153]$} \\
\hline & Proteopedia & http:// proteopedia.org (accessed on 29 December 2020) & [154] \\
\hline & PubChem & $\begin{array}{c}\text { http://pubchem.ncbi.nlm.nih.gov (accessed on } 29 \\
\text { December 2020) }\end{array}$ & [155] \\
\hline & RCSB Protein Data Bank (PDB) & https:/ /www.rcsb.org/ (accessed on 29 January 2021) & [156] \\
\hline & $\begin{array}{l}\text { Search Tool for the Retrieval of } \\
\text { Interacting Genes/Proteins (STRING) }\end{array}$ & https://string-db.org/ (accessed on 29 December 2020) & [157] \\
\hline & $\begin{array}{l}\text { Structures of Well-curated Extracts, } \\
\text { Existing Therapies, and Legally } \\
\text { regulated Entities for Accelerated } \\
\text { Discovery (SWEETLEAD) }\end{array}$ & $\begin{array}{c}\text { https://simtk.org/projects/sweetlead (accessed on } 29 \\
\text { December 2020) }\end{array}$ & [158] \\
\hline & SuperDRUG2 & $\begin{array}{c}\text { http://cheminfo.charite.de/superdrug2/ (accessed on } 29 \\
\text { December 2020) }\end{array}$ & [159] \\
\hline & $\begin{array}{l}\text { The NCGC Pharmaceutical Collection } \\
\text { (NPC) }\end{array}$ & https://tripod.nih.gov/npc/ (accessed on 29 December 2020) & [160] \\
\hline & $\begin{array}{l}\text { The Universal Protein Resource } \\
\text { (UniProt) }\end{array}$ & https:/ / www.uniprot.org/ (accessed on 29 December 2020) & [161] \\
\hline & ZINC & https:/ /zinc.docking.org/ (accessed on 29 December 2020) & [162] \\
\hline \multirow{4}{*}{ Pathway omics data } & $\begin{array}{l}\text { Kyoto Encyclopedia of Genes and } \\
\text { Genomes (KEGG) }\end{array}$ & $\begin{array}{c}\text { https://www.genome.jp/kegg/(accessed on } 29 \\
\text { December 2020) }\end{array}$ & {$[163,164]$} \\
\hline & $\begin{array}{l}\text { Mode of Action by NeTwoRk Analysis } \\
\text { (MANTRA) }\end{array}$ & https://mantra.tigem.it/ (accessed on 29 December 2020) & {$[165,166]$} \\
\hline & PathwayCommons & $\begin{array}{l}\text { https://www.pathwaycommons.org/ (accessed on } \\
29 \text { December 2020) }\end{array}$ & {$[167,168]$} \\
\hline & Reactome & https:/ / reactome.org/ (accessed on 29 December 2020) & [169] \\
\hline
\end{tabular}


Table 2. Cont.

\begin{tabular}{|c|c|c|c|}
\hline Category & Database & URL & Reference \\
\hline \multirow{6}{*}{ Genomics data } & ArrayExpress & $\begin{array}{c}\text { https://www.ebi.ac.uk/arrayexpress/ (accessed on } 29 \\
\text { December 2020) }\end{array}$ & [170] \\
\hline & GenBank & http:/ / www.ncbi.nlm.nih.gov (accessed on 29 December 2020) & {$[171]$} \\
\hline & Gene Expression Omnibus (NCBI-GEO) & $\begin{array}{c}\text { http: / / www.ncbi.nlm.nih.gov / geo / (accessed on } 29 \\
\text { December 2020) }\end{array}$ & [172] \\
\hline & Pharmacogene Variation (PharmVar) & https://www.pharmvar.org/ (accessed on 29 December 2020) & [173] \\
\hline & Sequence Read Archive (SRA) & $\begin{array}{c}\text { https: / trace.ncbi.nlm.nih.gov/Traces/sra / (accessed on } 29 \\
\text { December 2020) }\end{array}$ & [174] \\
\hline & $\begin{array}{l}\text { Single Nucleotide Polymorphism } \\
\text { database (dbSNP) }\end{array}$ & $\begin{array}{c}\text { https://www.ncbi.nlm.nih.gov/snp / (accessed on } 29 \\
\text { December 2020) }\end{array}$ & [175] \\
\hline \multirow{11}{*}{$\begin{array}{l}\text { Clinical and } \\
\text { disease information }\end{array}$} & ClinicalTrials & https: / / clinicaltrials.gov / (accessed on 29 December 2020) & - \\
\hline & $\begin{array}{l}\text { Comparative Toxicogenomics Database } \\
\text { (CTD) }\end{array}$ & http:/ / ctdbase.org/ (accessed on 29 December 2020) & [176] \\
\hline & DisGeNET & https:/ / www.disgenet.org/ (accessed on 29 December 2020) & {$[177]$} \\
\hline & Drugs@FDA & $\begin{array}{l}\text { https: / / www.accessdata.fda.gov/scripts/cder/daf/ (accessed } \\
\text { on } 29 \text { December 2020) }\end{array}$ & - \\
\hline & $\begin{array}{l}\text { Genome-wide Association Studies } \\
\text { (GWAS Catalog) }\end{array}$ & https://www.ebi.ac.uk/gwas/ (accessed on 29 December 2020) & [178] \\
\hline & $\begin{array}{l}\text { FDA Adverse Event Reporting System } \\
\text { (FAERS) }\end{array}$ & $\begin{array}{c}\text { https: / / open.fda.gov/data/faers/ (accessed on } 29 \\
\text { December 2020) }\end{array}$ & [179] \\
\hline & Online Mendelian in Man (OMIM) & $\begin{array}{c}\text { https:/ / www.ncbi.nlm.nih.gov/omim (accessed on } 28 \\
\text { August 2020) }\end{array}$ & [180] \\
\hline & OpenTargets & https://www.opentargets.org/ (accessed on 29 December 2020) & [181] \\
\hline & $\begin{array}{l}\text { Pharmacogenomics Knowledgebase } \\
\text { (PharmGKB) }\end{array}$ & https:/ /www.pharmgkb.org/ (accessed on 29 December 2020) & [182] \\
\hline & Side Effect Resource (SIDER) & http://sideeffects.embl.de/ (accessed on 29 December 2020) & {$[183]$} \\
\hline & Therapeutic Target Database (TTD) & http:/ /db.idrblab.net/ttd/ (accessed on 29 December 2020) & [184] \\
\hline \multirow{2}{*}{$\begin{array}{l}\text { Rare disease and } \\
\text { orphan drugs }\end{array}$} & eRAM & http:/ / www.unimd.org/eram/ (accessed on 29 December 2020) & {$[185]$} \\
\hline & $\begin{array}{l}\text { Orphanet (Oprhadata and Oprhanet } \\
\text { Rare Disease Ontology (ORDO)) }\end{array}$ & http:/ / www.orpha.net (accessed on 29 December 2020) & - \\
\hline
\end{tabular}

The disease-oriented approach is only applicable if the information of disease model is available and commonly used to study the contribution of pharmacological characteristics towards drug repositioning effort on a particular disease. Incorporated with clinical trial information, for adverse drug events (ADEs) and FDA approval labels that are available from ClinicalTrials (https:/ / clinicaltrials.gov / (accessed on 28 August 2020)), Drug@FDA (https:/ / www.accessdata.fda.gov/scripts/cder/daf/ (accessed on 28 August 2020)), side effect resource (SIDER) [183] and more, this strategy shows promise to identify off-target effects and predict the side effects and ADEs of drugs, leading to the improvement of the efficiency of drug discovery. As of December 2020, SIDER (version 4.1), a comprehensive side effects database, comprises 1430 drugs with 5868 side effects, resulting in 139,756 drug-side effect pairs [183]. This pair information can be applied as features in building a prediction model for disease indications, which has been implemented by Yang and Agarwal (2011) [194], Bisgin et al. (2014) [195], Ye et al. (2014) [196] and Sridhar et al. (2016) [197]. Compared with the drug-oriented approach, this requires more specific knowledge of drug and disease, including the gene signatures and disease pathways. Gene signatures, defined here as the sets of significantly up- and down-regulated genes, derived from disease omics data, are publicly available from the connectivity map (CMap) $[140,141]$ and the National Institutes of Health (NIH) library of integrated network based cellular signatures (LINCS) [151]. The advantage of integrating this information in drug repurposing is the added involvement of molecular- and/or genetic-level mechanisms, leading to the discovery of hidden mechanisms of drug and target [198]. The disease-specific pathway-based 
approach utilizes metabolic and signaling pathways, gene expression correlation and protein interaction network information to narrow down the target proteins/molecules from a general signaling networks to a specific network and predict the connection between drugs and disease. Notably, Kyoto Encyclopedia of Genes and Genomes (KEGG) $[163,164]$ is a frequently used database for such approach. The network is a way to discover informative relationships between drugs and targets that consists of two main entities, which are nodes and edges. The nodes in such network are represented as genes, proteins, molecules or other biological entities, while the edges are the connections that can be weighted based on the attributed information.

The blooming of drug repurposing resources and the advances in computational sciences give rise to the development of novel algorithms/tools and approaches that are capable of capitalizing on publicly available data. A list of widely used drug repurposing approaches is summarized in Table 3 with their respective required data and software tools, though the table is neither extensive nor exhaustive.

Although more databases are increasingly being established with enormous information, drug repositioning still remains as a tremendous challenge, especially for rare diseases, as drug repurposing studies are highly dependent on the available information and knowledge on disease mechanism, target protein/gene. Moreover, there are numerous available drug repurposing methods based on the availability of specific information. Hence, choosing the proper approaches and tools to mine novel knowledge based on the study of interest is extremely crucial, as otherwise the success of this approach may be hindered. It is necessary to emphasize the importance of integration of computational and experimental methods, and in-depth mechanistic computational pipelines or models in order to maximize the success rates of drug repurposing.

\subsection{Network-Driven Drug Discovery (NDD)}

Network biology epitomizes the cell as a cluster of molecules interacting with one another and aims to illustrate the emergence of cellular phenotype from the network of molecular interactions [227]. The networks can be regarded as establishing the mechanistic bridge between the constituent molecules of a cell and the phenotypes that the cells demonstrate. This perspective alone considers the cellular mechanism of disease to be materialized due to networks of pathological interactions that occur only in the disease state. In this context, drug discovery can, hence, be perceived as the search for agents that significantly disrupt these pathological networks. NDD, as a whole, aims to identify signatures of molecular perturbations; that is, collections of multiple proteins, that significantly disturb the structural integrity of the cellular networks bringing forth the targeted disease mechanism [228]. The search space of therapeutics, such as small molecules, biologics or other agents, can then be screened and narrowed down based on their ability to produce the identified perturbation signature. It should be acknowledged that the compounds of this scheme are not expected to directly bind to all proteins within the identified signature, but rather to produce a downstream, functional effect on the molecules making up the signature [229]. This approach is far removed from the traditional target-driven drug discovery that focuses on specific drug targets, whose downstream effects will significantly perturb the disease phenotype without much emphasis on cellular networks for understanding the underlying disease mechanisms. 
Table 3. List of software tools for the in silico drug repurposing studies (neither extensive nor exhaustive) based on the respective approach with the additional required data.

\begin{tabular}{|c|c|c|c|c|}
\hline Method & Approach & Required Data & Software To & s (Tool Name I Tool URL) \\
\hline \multirow{22}{*}{ Drug-oriented } & \multirow{5}{*}{ In silico screening } & \multirow{16}{*}{$\begin{array}{l}\text { Protein 3D structure, } \\
\text { chemical structure, } \\
\text { chemical information } \\
\text { (targets and ligands) }\end{array}$} & \multicolumn{2}{|c|}{ Protein structure prediction tools } \\
\hline & & & I-TASSER [199] & $\begin{array}{l}\text { https:/ / zhanglab.ccmb.med.umich. } \\
\text { edu/I-TASSER/ (accessed on } 29 \\
\text { December 2020) }\end{array}$ \\
\hline & & & Modeller [200] & $\begin{array}{l}\text { https://salilab.org/modeller/ } \\
\text { (accessed on } 29 \text { December 2020) }\end{array}$ \\
\hline & & & $\begin{array}{l}\text { transform-restrained } \\
\quad \text { Rosetta [201] }\end{array}$ & $\begin{array}{c}\text { http:/ / robetta.bakerlab.org/ (accessed } \\
\text { on } 29 \text { December 2020) }\end{array}$ \\
\hline & & & \multicolumn{2}{|r|}{ Docking } \\
\hline & \multirow{5}{*}{$\begin{array}{c}\text { Ligand based } \\
\text { screening and } \\
\text { molecular docking }\end{array}$} & & AutoDock [202] & $\begin{array}{l}\text { http:/ / autodock.scripps.edu/ } \\
\text { (accessed on } 29 \text { December 2020) }\end{array}$ \\
\hline & & & AutoDock Vina [203] & $\begin{array}{c}\text { http:/ / vina.scripps.edu/ (accessed on } \\
29 \text { December 2020) }\end{array}$ \\
\hline & & & $\begin{array}{l}\text { High Ambiguity Driven } \\
\text { protein-protein DOCKing } \\
\text { (HADDOCK [204]) }\end{array}$ & $\begin{array}{l}\text { https: } \\
\text { / / wenmr.science.uu.nl/haddock2.4/ } \\
\text { (accessed on 29 December 2020) }\end{array}$ \\
\hline & & & PatchDock [205] & $\begin{array}{l}\text { https: } \\
\text { / / bioinfo3d.cs.tau.ac.il/PatchDock/ } \\
\text { (accessed on 29 December 2020) }\end{array}$ \\
\hline & & & \multicolumn{2}{|c|}{$\begin{array}{l}\text { Pharmacophore mapping and inverse virtual docking (IVD) } \\
\text { programs }\end{array}$} \\
\hline & \multirow{6}{*}{$\begin{array}{l}\text { Fragment-based } \\
\text { screening }\end{array}$} & & BIOVIA Discovery Studio & $\begin{array}{l}\text { https:/ / discover.3ds.com/discovery- } \\
\text { studio-visualizer-download (accessed } \\
\text { on } 29 \text { December 2020) }\end{array}$ \\
\hline & & & INVDOCK [206] & $\begin{array}{c}\text { http://bidd.group / group/softwares / } \\
\text { invdock.htm (accessed on } 29 \\
\text { December 2020) }\end{array}$ \\
\hline & & & LigandScout [207] & $\begin{array}{l}\text { http: } \\
\text { //www.inteligand.com/ligandscout/ } \\
\text { (accessed on 29 December 2020) }\end{array}$ \\
\hline & & & PharmMap & $\begin{array}{l}\text { http://www.meilerlab.org/index. } \\
\text { php/research/show?w_text_id=32 } \\
\text { (accessed on } 29 \text { December 2020) }\end{array}$ \\
\hline & & & PharmMapper [208,209] & $\begin{array}{l}\text { http://www.lilab-ecust.cn/ } \\
\text { pharmmapper/ (accessed on } 29 \\
\text { December 2020) }\end{array}$ \\
\hline & & & ZINCPharmer [210] & $\begin{array}{l}\text { http:/ / zincpharmer.csb.pitt.edu/ } \\
\text { (accessed on } 29 \text { December 2020) }\end{array}$ \\
\hline & \multirow{6}{*}{$\begin{array}{l}\text { Drug similarity } \\
\text { studies }\end{array}$} & \multirow{6}{*}{$\begin{array}{l}\text { Chemical structure, } \\
\text { chemical information of } \\
\text { drugs, clinical trial } \\
\text { information, side effects } \\
\text { and adverse events, FDA } \\
\text { approval labels }\end{array}$} & \multicolumn{2}{|c|}{ Drug-drug similarities prediction and visualization } \\
\hline & & & ChemMine Tools [211] & $\begin{array}{l}\text { http:/ / chemmine.ucr.edu/ (accessed } \\
\text { on } 29 \text { December 2020) }\end{array}$ \\
\hline & & & ChemTreeMap [212] & $\begin{array}{c}\text { https:// chemtreemap.readthedocs.io/ } \\
\text { en/latest/ (accessed on } 29 \\
\text { December 2020) }\end{array}$ \\
\hline & & & $\begin{array}{l}\text { Compound Specific } \\
\text { bioActivity DENdrogram } \\
\text { (C-SPACE [213]) }\end{array}$ & $\begin{array}{l}\text { http:/ / cspade.fimm.fi/ (accessed on } \\
29 \text { December 2020) }\end{array}$ \\
\hline & & & \multicolumn{2}{|c|}{ Drug-drug similarities and drug-target interaction prediction } \\
\hline & & & SuperPred [214] & $\begin{array}{l}\text { https://prediction.charite.de/ } \\
\text { (accessed on } 29 \text { December 2020) }\end{array}$ \\
\hline
\end{tabular}


Table 3. Cont.

\begin{tabular}{|c|c|c|c|c|}
\hline Method & Approach & Required Data & \multicolumn{2}{|c|}{ Software Tools (Tool Name I Tool URL) } \\
\hline \multirow{15}{*}{$\begin{array}{l}\text { Disease-/therapy- } \\
\text { oriented }\end{array}$} & \multirow{4}{*}{$\begin{array}{l}\text { Signature-based drug } \\
\text { repurposing }\end{array}$} & \multirow{4}{*}{$\begin{array}{c}\text { Gene signatures } \\
\text { information, } \\
\text { disease/genetics data, } \\
\text { drug omics data }\end{array}$} & \multicolumn{2}{|c|}{ Signature-based drug repurposing tool } \\
\hline & & & Cogena [215] & $\begin{array}{l}\text { http://bioconductor.org/packages/ } \\
\text { release/bioc/html/cogena.html } \\
\text { (accessed on } 29 \text { December 2020) }\end{array}$ \\
\hline & & & ksRepo [216] & $\begin{array}{l}\text { https:/ / github.com/adam-sam- } \\
\text { brown/ksRepo (accessed on } 29 \\
\text { December 2020) }\end{array}$ \\
\hline & & & DrugSig [217] & $\begin{array}{c}\text { http:/ / biotechlab.fudan.edu.cn/ } \\
\text { database/drugsig/ (accessed on } 29 \\
\text { December 2020) }\end{array}$ \\
\hline & \multirow{5}{*}{$\begin{array}{l}\text { Pathway-/network- } \\
\text { based drug } \\
\text { repurposing }\end{array}$} & \multirow{11}{*}{$\begin{array}{l}\text { General drug information, } \\
\text { pathway information }\end{array}$} & \multicolumn{2}{|c|}{ Network-based drug repurposing tool } \\
\hline & & & $\begin{array}{c}\text { Drug Repurposing } \\
\text { Recommendation System } \\
\text { (DRRS [218]) }\end{array}$ & $\begin{array}{l}\text { http:/ / bioinformatics.csu.edu.cn/ } \\
\text { resources / softs / DrugRepositioning/ } \\
\text { DRRS/index.html (accessed on } 29 \\
\text { December 2020) }\end{array}$ \\
\hline & & & DrugNet [219] & $\begin{array}{l}\text { http://genome.ugr.es:9000/ drugnet } \\
\text { (accessed on } 29 \text { December 2020) }\end{array}$ \\
\hline & & & $\begin{array}{l}\text { GeneDiseaseRepositioning } \\
\text { [220] }\end{array}$ & $\begin{array}{c}\text { https:/ / bitbucket.org/ncl-intbio/ } \\
\text { genediseaserepositioning/src/ } \\
\text { master/ (accessed on } 29 \text { December } \\
\text { 2020) }\end{array}$ \\
\hline & & & $\begin{array}{l}\text { Predicting Drugs having } \\
\text { Opposite effects on } \\
\text { Disease genes (PDOD } \\
\text { [221]) }\end{array}$ & $\begin{array}{l}\text { http:/ / gto.kaist.ac.kr/pdod/index. } \\
\text { php/main (accessed on } 29 \text { December } \\
\text { 2020) }\end{array}$ \\
\hline & \multirow{6}{*}{$\begin{array}{l}\text { Targeted } \\
\text { mechanism-based } \\
\text { drug repurposing }\end{array}$} & & \multicolumn{2}{|c|}{ Network visualization } \\
\hline & & & Cytoscape [222] & $\begin{array}{c}\text { https:/ / cytoscape.org/ (accessed on } 29 \\
\text { December 2020) }\end{array}$ \\
\hline & & & GeneMANIA [223] & $\begin{array}{c}\text { https://genemania.org/ (accessed on } \\
29 \text { December 2020) }\end{array}$ \\
\hline & & & Pathway Studio [224] & $\begin{array}{l}\text { https:/ / www.pathwaystudio.com/ } \\
\text { (accessed on } 29 \text { December 2020) }\end{array}$ \\
\hline & & & PATIKAweb [225] & $\begin{array}{l}\text { http:/ / www.cs.bilkent.edu.tr/ } \\
\sim \text { patikaweb / (accessed on } 29 \\
\text { December 2020) }\end{array}$ \\
\hline & & & VisANT [226] & $\begin{array}{c}\text { http: } \\
\text { / / www.visantnet.org/visantnet.html } \\
\text { (accessed on 29 December 2020) }\end{array}$ \\
\hline
\end{tabular}

As opposed to the canonical SMN-independent treatment based on many diseasemodifying pathways, potential drug targets may be found on the periphery of the pathways using the NDD approach. A network analysis based on the two main proteins (Figure 7), SMN1 and SMN2, as protein input in GeneMANIA (https://genemania.org/ (accessed on 29 December 2020)) [223], has generated a network of putative interacting proteins that works in unison to bring about the phenotypes as seen in SMA. Proteins such as GEMINs [230], SNRPB [231], DDX20 [232] and PFN2 [233] appear to be highly correlated to the functioning of SMN1 and SMN2. These proteins are essential to SMN in forming macromolecular complexes (e.g., SMN-GEMINs, SMN-snRNPs) to chaperon the assembly of small nuclear ribonucleoproteins (snRNPs) that are vital to pre-mRNA splicing for producing the final SMN1 and SMN2 proteins [230]. Modulating these proteins in the cellular network within the context of SMA may serve as an opportunity to develop novel therapeutics complementary to the conventional SMN-dependent treatments in addressing the challenge of creating a robust and sustainable solution to curing SMA. 


\section{Networks}

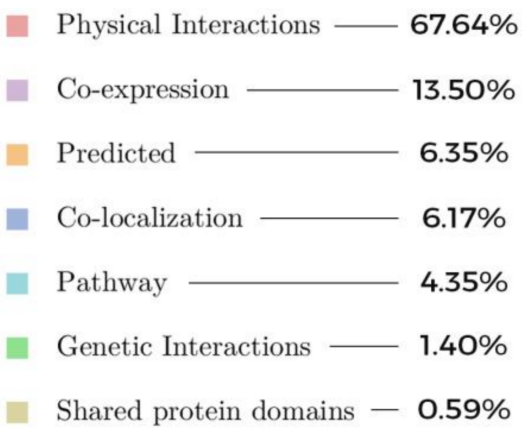

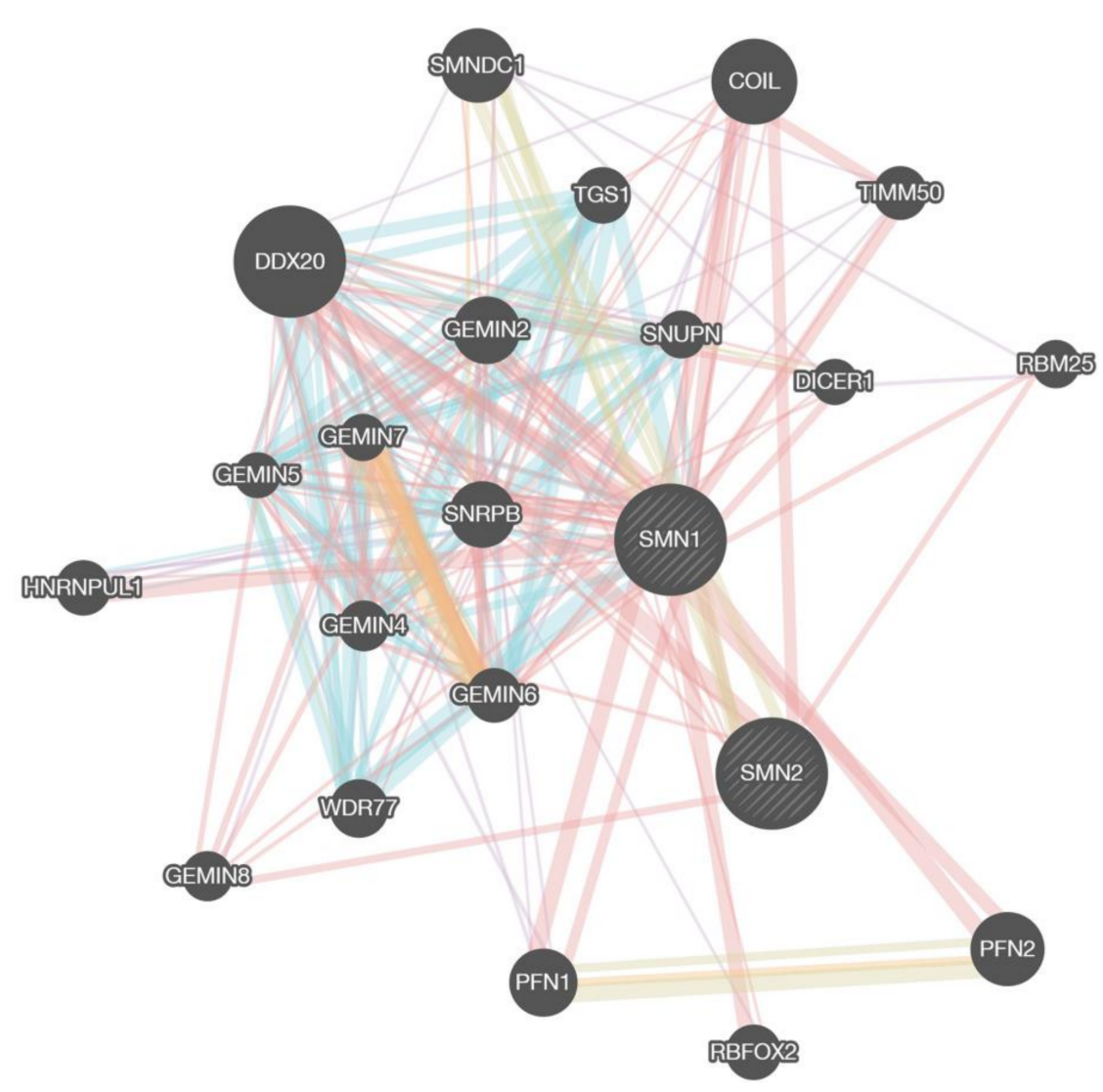

Figure 7. Protein network based on two main proteins, SMN1 and SMN2, and their respective interactions with other proteins related to SMA, generated using GeneMANIA [223] (https:/ / genemania.org/ (accessed on 29 December 2020)). The most prevalent network relationship, reported by literature, among the proteins is physical interactions (pink color) at $67.64 \%$, as visually shown by the line thickness, while the smallest belong to the shared protein domains at $0.59 \%$.

With the advances of network biology, the rapid growth of publicly available biomedical data and the advanced computational analytics, the NDD approach, a mechanistic based approach, proposes an alternative to identify the novel target as potential SMNindependent treatment. Collectively, a comprehensive analysis of drug-protein interactions on a genome-wide scale is crucial and provides beneficial effects in drug discovery, especially for polypharmacology and phenotypic screening [234]. Several studies has discovered many disease-modifying pathways in SMA, such as the RhoA/Rho kinase (ROCK) [79,235,236], the cyclic adenosine monophosphate (cAMP) pathway [237], the extracellular regulated kinase (ERK) [235,238], the c-Jun N-terminal Kinase (JNK) [239] and the p53-pathway [240], which show promise as further SMA therapy development [100]. For instance, Y-27632 and fasudil, ROCK inhibitors, have been suggested to improve the lifespan of an intermediate SMA mouse model $\left(\mathrm{Smn}^{2 \mathrm{~B} /-}\right)$ without any effects on the expression levels of the SMN protein [236,241,242]. Discussing all the listed signaling pathways in detail would go beyond the scope of this review. Nonetheless, with the given example, it is clear that a more in-depth level of understanding those pathways is likely to provide further insights in identifying novel therapeutic targets in a much shorter period.

\subsection{AI-Assisted Drug Discovery (AID)}

AI application to drug discovery is not a new technology and started around 1990 [243-245]. Driven by the big data in the field of biomedical and/or healthcare, the advancement of algorithms and technology such as deep learning (DL), graphical processing units (GPUs) and Google's tensor processing units (TPUs) enable better predictive capability by shortening the computing time [246,247]. To date, AI has been extensively adopted to support healthcare services and research. Virtual screening [248], quantitative structure-activity 
relationship (QSAR) [249], de novo drug design [250,251], drug repurposing [252] and chemical space visualization [253] utilized ML extensively to reduce the gap in the conventional methods in drug discovery, while DL shows promise in proposing potent drug candidates using their properties and toxicity risks [9]. Uptake from the pharmaceutical industry is still lagged, especially for rare diseases. Given the breadth of AID, we summarized the pipeline and its pre-requisites (Figure 8).
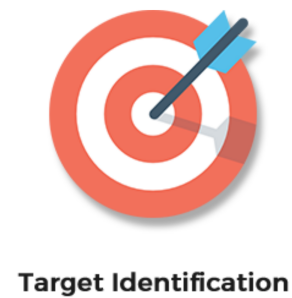
and Validation

Applications in Drug Discovery

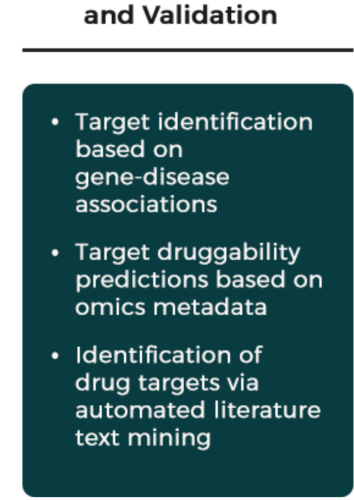

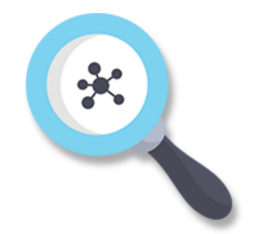
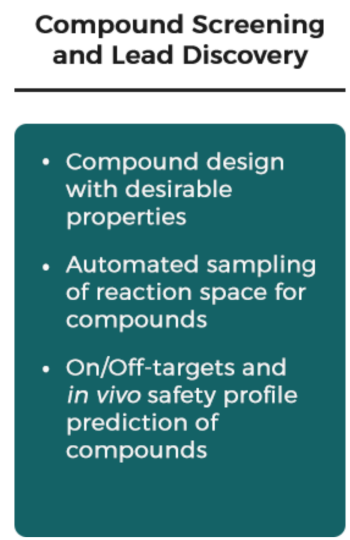

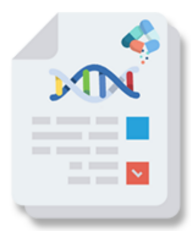

Preclinica Development

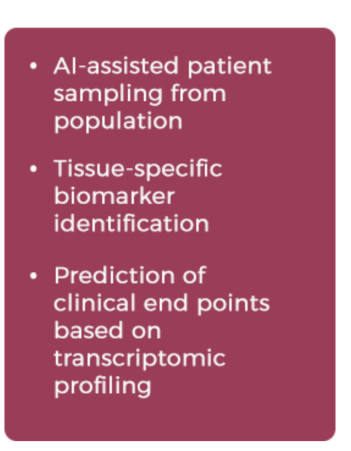

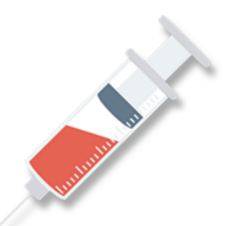

Clinical Development

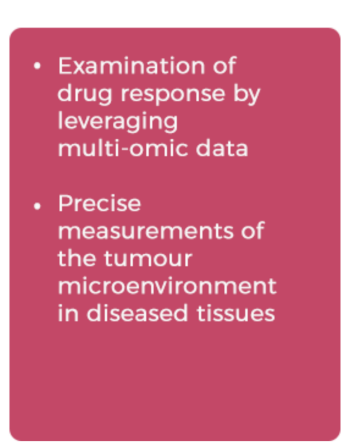

Figure 8. Machine learning applications in the drug discovery pipeline. Promising developments of pioneering ML research has brought forth unprecedented advances across various stages of the traditional drug development pipeline, especially the concept of automation in the early drug discovery process of target identification and validation \& compound screening and lead discovery; relying on the domain of NLP in AI to find prospective drug targets by scanning upon thousands of relevant literature based on contextual information in research papers, and integrating AI with synthesis robots to explore unknown reaction space to search for drug candidates in which multiple chemical experiments are conducted automatically in real-time to assess the reproducibility of chemical reactions and discover new reaction outcomes. AI in the preclinical development has been a game-changer for patient selection in Phase II and III clinical trials by identifying and predicting human-relevant biomarkers of diseases, thus preventing unnecessary toxicities and side effects of consuming the experimental drugs for the designated patients [254].

To date, there are only a few drugs that utilized AID that are being conducted for clinical trials; nonetheless, none of them have proceeded to Phase III and above. DSP-1181, reportedly the first AID-designed drug in January 2020, which has begun with human testing, was developed by Exscientia with Japan's Sumitomo Dainippon Pharma [255] with the intention of treating obsessive compulsive disorder (OCD) patients. Additionally, to date, there are no studies utilizing AI for the drug development of SMA; however, only some case studies of AI being implemented to tackle one of the rare diseases that closely related to SMA, which is amyotrophic lateral sclerosis (ALS). The breakthroughs from BenevolentAI and Verge Genomics have demonstrated promises for therapeutic approaches in ALS by leveraging the AI technology $[256,257]$. A plethora of studies have successfully implemented ML models in ALS research, commonly with random forests (RF) [258], support vector machines (SVM) [259], neural networks (NN) [260] and more. Chiefly, although all case studies related to ALS are still being evaluated, these studies may serve as a proxy, so we can extrapolate the efficacy of AI methods employed by others in developing drugs to treat SMA.

Through a closer inspection of AI techniques in accelerating drug discovery, there are several common machine learning methods being employed to address the challenges in two major areas of drug development: (i) design and discovery and preclinical research; 
and (ii) clinical research and safety monitoring (Table 4). In the first major area, a generative model has been utilized for de novo drug design, as reported by a study conducted by Prykhodko et al. (2019), who proposed a novel deep learning architecture, LatentGAN, which combines an autoencoder and a generative adversarial neural network (GAN) to generate novel structures [261]. The autoencoder was first pre-trained on one-hot encoded SMILES data derived from ChEMBL database for mapping structures to latent vectors. These outputs are then fed into the GAN architecture as training data to generate novel latent vectors that were later decoded in the autoencoder to obtain the SMILES strings of the novel molecule. It was found that the LatentGAN was able to generate similar drug-like compounds after training on a randomly selected 100,000 ChEMBL subset data when compared to the 200,000 generated compounds from LatentGAN in a 2D PCA plot (explained variance $74.1 \%$ ) to examine the coverage of the chemical space. A similar study was carried out by Kadurin et al. (2017) in investigating the viability of utilizing GANs and autoencoders to generate new molecules with desired molecular properties in silico [262].

Table 4. Utility of machine learning methods in addressing the challenges of drug development.

\begin{tabular}{|c|c|c|}
\hline Machine Learning Methods & Area of Drug Development & Reference \\
\hline $\begin{array}{ll}\text { - } & \text { Generative model } \\
\text { - } & \text { Reinforcement learning }\end{array}$ & $\begin{array}{l}\text { Design and Discovery and Preclinical Research } \\
\text { - } \quad \text { Synthesis prediction and de novo drug design } \\
\text { - Virtual drug screening and drug } \\
\text { target identification }\end{array}$ & [261-263] \\
\hline $\begin{array}{l}\text { - Deep representational } \\
\text { learning } \\
\text { - } \quad \text { Graph embeddings }\end{array}$ & $\begin{array}{l}\text { Clinical Research and Safety Monitoring } \\
\text { - } \quad \text { Clinical trial recruitment } \\
\text { - } \quad \text { Adverse drug effects, polypharmacy and } \\
\text { drug-food interaction prediction }\end{array}$ & [264-266] \\
\hline
\end{tabular}

In the second major area of clinical research and safety monitoring, deep representational learning was used in a novel architecture, DeepEnroll, to streamline the process of finding qualified patients for clinical trials with an NLP-based model called Bidirectional Encoder Representations from Transformers (BERT), which utilized heterogeneous data from EC (Text Data) and patient EHR (Tabular Data) to train the model and optimize the patient-trial matching score in a cross-modal inference fashion [266]. DeepEnroll has outperformed the best baseline by up to $12.4 \%$ in an averaged-F1 score. In addressing the potential side effects of multi-drug combination administration (polypharmacy), Zitnik et al. (2018) presented a graph-embedding-based approach-Decagon-which builds multimodal graphs of protein-protein interactions and drug-protein target interactions and the polypharmacy side effects to model each relationship with nodes (i.e., drugs, proteins) and labeled edges (i.e., side effects) for multi-relational link prediction [265]. It was found that Decagon can accurately predict polypharmacy side effects, outperforming baselines by up to $69 \%$. In a similar avenue of research focusing on drug-target interactions, DeepDTA, a convolutional neural networks (CNN)-based approach, was proposed to predict drug-target binding affinity using only sequences of proteins and drugs in a 1D representational state in the CNN model [264]. It has outperformed two state-of-the-art methods for DT binding affinity prediction, KronRLS algorithm and SimBoost, based on the concordance index $(\mathrm{CI})$ to measure the model performance.

\section{Conclusions}

The task of finding a successful, novel drug as treatment for common diseases is predominantly a daunting yet arduous process, which is even more challenging for a rare genetic neurological disorder such as SMA. Many research and development pharmaceutical companies and research institutions are hesitant to pursue the drug development for rare diseases due to the small market size, high cost, possibly low return and lack of information about the disease, drugs and corresponding drug targets. Recently, CADD approaches have shown promising potentials in facilitating the drug discovery process 
and may be able to overcome the limiting bottlenecks of its traditional counterparts. Along with the advances of the knowledge of computational biology and informatics database, the opportunities provided by drug repurposing cannot be underestimated. The interactions of a drug and a target is a critical point of drug discovery. This information aids to establish correlations between diseases and targets in order to determine the therapeutic effect of drugs on various diseases. Hence, the well-known drug-disease relationships that has been established using network biology will help accelerate the target identification and lead optimization process for pre-clinical drug development. Integrated with the domain-specific AI in the 'chemical big data,' the novel approach could potentially serve as a panacea by increasing the efficiency of certain aspects of the drug discovery process.

Despite the promising potential offered by CADD, there are several challenges, including the access of databases consisting all the approved drugs and their detailed profiles, in-depth knowledge of disease, particularly for multifaceted disease, among others [267] to capitalize the benefit of CADD in advancing the domain of drug research and development. In spite of the recent advocacy of 'open science' in the scientific community, proprietary databases still remain few and far between. In addition, errors can be found in publicly available data, such as drug structures and their chemical profiles, among others, leading to the inevitable failure of identifying lead targets accurately. Research that involved multidisciplinary fields may face the challenges of integrating the complex theories into practical applications. This could only become more profound when dealing with the governance of data quality such as missing, biased and inaccurate data. Demonstrating this, the lack of the structural data of promising ligand or drug hinders the identification of potential drug-target interaction. Additionally, the protein-protein interaction network for a less-studied disease may mislead the drug discovery process. Addressing these challenges are by no means a trivial endeavor; monumental efforts must be put forth to develop a standardized, generic CADD framework to complement the traditional approach of creating novel yet effective therapeutics for both common and uncommon diseases. In light of such call-to-action, the various techniques and methodologies examined in this study may serve as a precedent in establishing the cornerstone for the CADD framework.

Author Contributions: Conceptualization, L.C.C. and S.-B.C.; Writing-Original Draft Preparation, L.C.C., G.G. and J.M.L.; Writing-Review and Editing, W.W.Y.Y. and S.-B.C.; Visualization, L.C.C. and J.M.L.; Supervision, W.W.Y.Y. and S.-B.C. All authors have read and agreed to the published version of the manuscript.

Funding: This research received no external funding and the Article Processing Charge was funded by Perdana University, Malaysian Medical Association (MMA) (Grant number: 770-2511-Grant Search MMA 2020) and Asia Pacific Bioinformatics Network (APBioNET).

Acknowledgments: We gratefully acknowledge the financial support from the Malaysian Ministry of Education under Fundamental Research Grant Scheme (FRGS) (Grant number: FRGS/1/2018/SKK08/ PERDANA/03/1) and the Adnuri SMA Research Center (M) Sdn. Bhd. (Grant number: 41003045). Gayatri Gandhi received financial support from the FRGS grant. We thank Siti Safura binti Jaapar for her constructive comments and suggestions on this review and Spinal Muscular Atrophy Malaysia (SMAM).

Conflicts of Interest: The authors declare no conflict of interest.

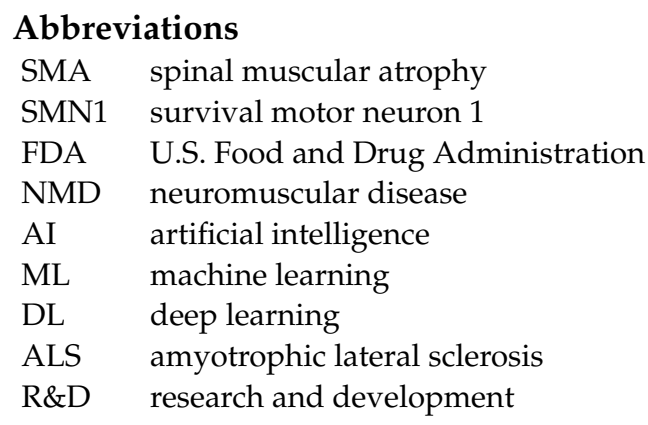




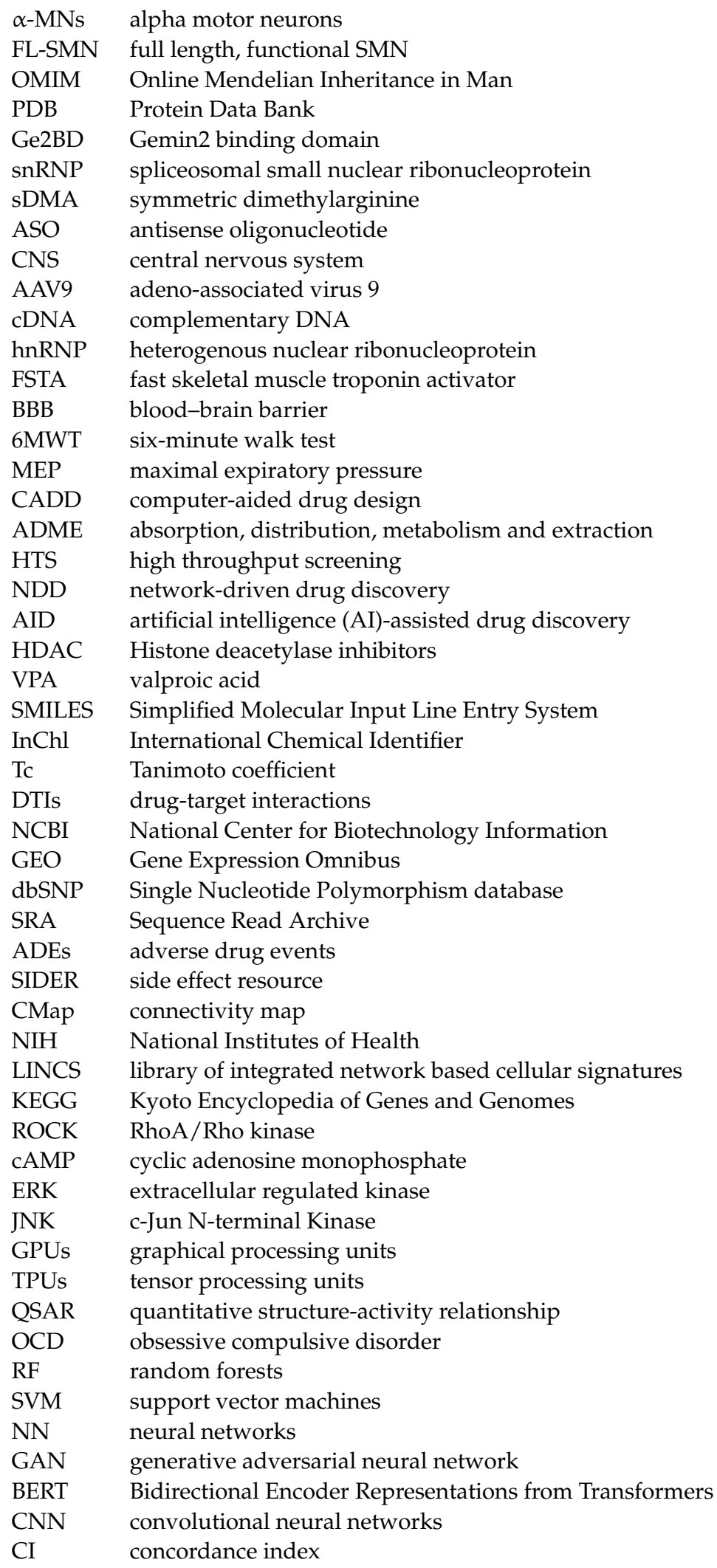

\section{References}

1. Cherry, J.J.; Kobayashi, D.T.; Lynes, M.M.; Naryshkin, N.N.; Tiziano, F.D.; Zaworski, P.G.; Rubin, L.L.; Jarecki, J. Assays for the Identification and Prioritization of Drug Candidates for Spinal Muscular Atrophy. Assay Drug Dev. Technol. 2014, 12, 315-341. [CrossRef]

2. Kolb, S.J.; Kissel, J.T. Spinal Muscular Atrophy. Neurol. Clin. 2015, 33, 831-846. [CrossRef] 
3. Lefebvre, S.; Bürglen, L.; Reboullet, S.; Clermont, O.; Burlet, P.; Viollet, L.; Benichou, B.; Cruaud, C.; Millasseau, P.; Zeviani, M.; et al. Identification and Characterization of a Spinal Muscular Atrophy-Determining Gene. Cell 1995, 80, 155-165. [CrossRef]

4. Kolb, S.J.; Kissel, J.T. Spinal Muscular Atrophy: A Timely Review. Arch. Neurol. 2011. [CrossRef] [PubMed]

5. Lefebvre, S.; Burlet, P.; Liu, Q.; Bertrandy, S.; Clermont, O.; Munnich, A.; Dreyfuss, G.; Melki, J. Correlation between Severity and SMN Protein Level in Spinal Muscular Atrophy. Nat. Genet. 1997, 16, 265-269. [CrossRef] [PubMed]

6. Wurster, C.D.; Ludolph, A.C. Nusinersen for Spinal Muscular Atrophy. Ther. Adv. Neurol. Disord. 2018, 11, 175628561875445. [CrossRef]

7. Mahajan, R. Onasemnogene Abeparvovec for Spinal Muscular Atrophy: The Costlier Drug Ever. Int. J. Appl. Basic Med. Res. 2019, 9, 127. [CrossRef] [PubMed]

8. Tabet, R.; El Bitar, S.; Zaidan, J.; Dabaghian, G. Spinal Muscular Atrophy: The Treatment Approved. Cureus 2017. [CrossRef] [PubMed]

9. Mak, K.-K.; Pichika, M.R. Artificial Intelligence in Drug Development: Present Status and Future Prospects. Drug Discov. Today 2019, 24, 773-780. [CrossRef]

10. Otsuki, N.; Arakawa, R.; Kaneko, K.; Aoki, R.; Arakawa, M.; Saito, K. A New Biomarker Candidate for Spinal Muscular Atrophy: Identification of a Peripheral Blood Cell Population Capable of Monitoring the Level of Survival Motor Neuron Protein. PLoS ONE 2018, 13, e0201764. [CrossRef]

11. Kolb, S.J. Spinal Muscular Atrophy. Arch. Neurol. 2011, 68, 979. [CrossRef] [PubMed]

12. Crawford, T.O.; Pardo, C.A. The Neurobiology of Childhood Spinal Muscular Atrophy. Neurobiol. Dis. 1996, 3, 97-110. [CrossRef]

13. Markowitz, J.A.; Tinkle, M.B.; Fischbeck, K.H. Spinal Muscular Atrophy in the Neonate. J. Obstet. Gynecol. Neonatal Nurs. 2004, 33, 12-20. [CrossRef] [PubMed]

14. DiDonato, C.J.; Parks, R.J.; Kothary, R. Development of a Gene Therapy Strategy for the Restoration of Survival Motor Neuron Protein Expression: Implications for Spinal Muscular Atrophy Therapy. Hum. Gene Ther. 2003, 14, 179-188. [CrossRef] [PubMed]

15. Tisdale, S.; Pellizzoni, L. Disease Mechanisms and Therapeutic Approaches in Spinal Muscular Atrophy. J. Neurosci. 2015, 35, 8691-8700. [CrossRef]

16. Sumner, C.J.; Crawford, T.O. Two Breakthrough Gene-Targeted Treatments for Spinal Muscular Atrophy: Challenges Remain. J. Clin. Investig. 2018, 128, 3219-3227. [CrossRef]

17. Lunn, M.R.; Wang, C.H. Spinal Muscular Atrophy. Lancet 2008, 371, 2120-2133. [CrossRef]

18. Roberts, D.F.; Chavez, J.; Court, S.D.M. The Genetic Component in Child Mortality. Arch. Dis. Child. 1970, 45, 33-38. [CrossRef]

19. Wirth, B. An Update of the Mutation Spectrum of the Survival Motor Neuron Gene (SMN1) in Autosomal Recessive Spinal Muscular Atrophy (SMA). Hum. Mutat. 2000, 15, 228-237. [CrossRef]

20. D'Amico, A.; Mercuri, E.; Tiziano, F.D.; Bertini, E. Spinal Muscular Atrophy. Orphanet J. Rare Dis. 2011. [CrossRef]

21. Ogino, S.; Leonard, D.G.B.; Rennert, H.; Ewens, W.J.; Wilson, R.B. Genetic Risk Assessment in Carrier Testing for Spinal Muscular Atrophy. Am. J. Med Genet. 2002, 110, 301-307. [CrossRef] [PubMed]

22. Prior, T.W.; Snyder, P.J.; Rink, B.D.; Pearl, D.K.; Pyatt, R.E.; Mihal, D.C.; Conlan, T.; Schmalz, B.; Montgomery, L.; Ziegler, K.; et al. Newborn and Carrier Screening for Spinal Muscular Atrophy. Am. J. Med Genet. Part A 2010, 152A, 1608-1616. [CrossRef] [PubMed]

23. Schorling, D.C.; Pechmann, A.; Kirschner, J. Advances in Treatment of Spinal Muscular Atrophy-New Phenotypes, New Challenges, New Implications for Care. J. Neuromuscul. Dis. 2020, 7, 1-13. [CrossRef]

24. Feng, Y.; Ge, X.; Meng, L.; Scull, J.; Li, J.; Tian, X.; Zhang, T.; Jin, W.; Cheng, H.; Wang, X.; et al. The next Generation of Population-Based Spinal Muscular Atrophy Carrier Screening: Comprehensive Pan-Ethnic SMN1 Copy-Number and Sequence Variant Analysis by Massively Parallel Sequencing. Genet. Med. 2017, 19, 936-944. [CrossRef] [PubMed]

25. Verhaart, I.E.C.; Robertson, A.; Wilson, I.J.; Aartsma-Rus, A.; Cameron, S.; Jones, C.C.; Cook, S.F.; Lochmüller, H. Prevalence, Incidence and Carrier Frequency of 5q-Linked Spinal Muscular Atrophy-A Literature Review. Orphanet J. Rare Dis. 2017, 12, 124. [CrossRef] [PubMed]

26. Sugarman, E.A.; Nagan, N.; Zhu, H.; Akmaev, V.R.; Zhou, Z.; Rohlfs, E.M.; Flynn, K.; Hendrickson, B.C.; Scholl, T.; Sirko-Osadsa, D.A.; et al. Pan-Ethnic Carrier Screening and Prenatal Diagnosis for Spinal Muscular Atrophy: Clinical Laboratory Analysis of $>72,400$ Specimens. Eur. J. Hum. Genet. 2012, 20, 27-32. [CrossRef]

27. Kvasnicová, M.; Styková, J.; Hudec, P. Incidence of Spinal Muscular Atrophy and Duchenne's Muscular Dystrophy in the Juvenile Population of Central Slovakia. Bratislavské Lekárske Listy 1994, 95, 78-82. [PubMed]

28. Ludvigsson, P.; Olafsson, E.; Hauser, W.A. Spinal Muscular Atrophy: Incidence in Iceland. Neuroepidemiology 1999, 18, 265-269. [CrossRef] [PubMed]

29. Zaldivar, T.; Montejo, Y.; Acevedo, A.M.; Guerra, R.; Vargas, J.; Garofalo, N.; Alvarez, R.; Alvarez, M.A.; Hardiman, O. Evidence of Reduced Frequency of Spinal Muscular Atrophy Type I in the Cuban Population. Neurology 2005, 65, 636-638. [CrossRef]

30. Hendrickson, B.C.; Donohoe, C.; Akmaev, V.R.; Sugarman, E.A.; Labrousse, P.; Boguslavskiy, L.; Flynn, K.; Rohlfs, E.M.; Walker, A.; Allitto, B.; et al. Differences in SMN1 Allele Frequencies among Ethnic Groups within North America. J. Med Genet. 2009, 46, 641-644. [CrossRef]

31. MacDonald, W.K.; Hamilton, D.; Kuhle, S. SMA Carrier Testing: A Meta-Analysis of Differences in Test Performance by Ethnic Group. Prenat. Diagn. 2014, 34, 1219-1226. [CrossRef] 
32. Russman, B.S. Spinal Muscular Atrophy: Clinical Classification and Disease Heterogeneity. J. Child Neurol. 2007, $22,946-951$. [CrossRef]

33. Arnold, W.D.; Kassar, D.; Kissel, J.T. Spinal Muscular Atrophy: Diagnosis and Management in a New Therapeutic Era. Muscle Nerve 2015, 51, 157-167. [CrossRef]

34. Campbell, L.; Potter, A.; Ignatius, J.; Dubowitz, V.; Davies, K. Genomic Variation and Gene Conversion in Spinal Muscular Atrophy: Implications for Disease Process and Clinical Phenotype. Am. J. Hum. Genet. 1997, 61, 40-50. [CrossRef] [PubMed]

35. Bowerman, M.; Becker, C.G.; Yáñez-Muñoz, R.J.; Ning, K.; Wood, M.J.A.; Gillingwater, T.H.; Talbot, K. Therapeutic Strategies for Spinal Muscular Atrophy: SMN and Beyond. Dis. Models Mech. 2017, 10, 943-954. [CrossRef] [PubMed]

36. Paushkin, S.; Charroux, B.; Abel, L.; Perkinson, R.A.; Pellizzoni, L.; Dreyfuss, G. The Survival Motor Neuron Protein of Schizosacharomyces Pombe. J. Biol. Chem. 2000, 275, 23841-23846. [CrossRef] [PubMed]

37. Tariq, F.; Holcik, M.; MacKenzie, A. Spinal Muscular Atrophy: Classification, Diagnosis, Background, Molecular Mechanism and Development of Therapeutics. In Neurodegenerative Diseases; InTech: London, UK, 2013. [CrossRef]

38. Cartegni, L.; Krainer, A.R. Disruption of an SF2/ASF-Dependent Exonic Splicing Enhancer in SMN2 Causes Spinal Muscular Atrophy in the Absence of SMN1. Nat. Genet. 2002, 30, 377-384. [CrossRef]

39. Kashima, T.; Manley, J.L. A Negative Element in SMN2 Exon 7 Inhibits Splicing in Spinal Muscular Atrophy. Nat. Genet. 2003, 34, 460-463. [CrossRef]

40. Monani, U.R.; Lorson, C.L.; Parsons, D.W.; Prior, T.W.; Androphy, E.J.; Burghes, A.H.; McPherson, J.D. A Single Nucleotide Difference That Alters Splicing Patterns Distinguishes the SMA Gene SMN1 from the Copy Gene SMN2. Hum. Mol. Genet. 1999, 8, 1177-1183. [CrossRef]

41. Gennarelli, M.; Lucarelli, M.; Capon, F.; Pizzuti, A.; Merlini, L.; Angelini, C.; Novelli, G.; Dallapiccola, B. Survival Motor-Neuron Gene Transcript Analysis in Muscles from Spinal Muscular-Atrophy Patients. Biochem. Biophys. Res. Commun. 1995, 213, 342-348. [CrossRef]

42. Rad, I.A. Mutation Spectrum of Survival Motor Neuron Gene in Spinal Muscular Atrophy. J. Down Syndr. Chromosome Abnorm. 2017, 3, 1-2. [CrossRef]

43. Calucho, M.; Bernal, S.; Alías, L.; March, F.; Venceslá, A.; Rodríguez-Álvarez, F.J.; Aller, E.; Fernández, R.M.; Borrego, S.; Millán, J.M.; et al. Correlation between SMA Type and SMN2 Copy Number Revisited: An Analysis of 625 Unrelated Spanish Patients and a Compilation of 2834 Reported Cases. Neuromuscul. Disord. 2018, 28, 208-215. [CrossRef]

44. Al Dakhoul, S. Very Severe Spinal Muscular Atrophy (Type 0). Avicenna J. Med. 2017, 7, 32. [CrossRef] [PubMed]

45. Feldkötter, M.; Schwarzer, V.; Wirth, R.; Wienker, T.F.; Wirth, B. Quantitative Analyses of SMN1 and SMN2 Based on Real-Time LightCycler PCR: Fast and Highly Reliable Carrier Testing and Prediction of Severity of Spinal Muscular Atrophy. Am. J. Hum. Genet. 2002, 70, 358-368. [CrossRef] [PubMed]

46. Wirth, B.; Brichta, L.; Schrank, B.; Lochmüller, H.; Blick, S.; Baasner, A.; Heller, R. Mildly Affected Patients with Spinal Muscular Atrophy Are Partially Protected by an Increased SMN2 Copy Number. Hum. Genet. 2006, 119, 422-428. [CrossRef] [PubMed]

47. Cuscó, I.; Barceló, M.J.; Rojas-García, R.; Illa, I.; Gámez, J.; Cervera, C.; Pou, A.; Izquierdo, G.; Baiget, M.; Tizzano, E.F. SMN2 Copy Number Predicts Acute or Chronic Spinal Muscular Atrophy but Does Not Account for Intrafamilial Variability in Siblings. J. Neurol. 2006, 253, 21-25. [CrossRef]

48. Burghes, A.H.M.; Beattie, C.E. Spinal Muscular Atrophy: Why Do Low Levels of Survival Motor Neuron Protein Make Motor Neurons Sick? Nat. Rev. Neurosci. 2009, 10, 597-609. [CrossRef] [PubMed]

49. Monani, U.R.; Sendtner, M.; Coovert, D.D.; Parsons, D.W.; Andreassi, C.; Le, T.T.; Jablonka, S.; Schrank, B.; Rossol, W.; Prior, T.W.; et al. The Human Centromeric Survival Motor Neuron Gene (SMN2) Rescues Embryonic Lethality in Smn-/-Mice and Results in a Mouse with Spinal Muscular Atrophy. Hum. Mol. Genet. 2000, 9, 333-339. [CrossRef]

50. Munsat, T.L. International SMA Collaboration. Neuromuscul. Disord. 1991. [CrossRef]

51. Dubowitz, V. Very Severe Spinal Muscular Atrophy (SMA Type 0): An Expanding Clinical Phenotype. Eur. J. Paediatr. Neurol. 1999, 3, 49-51. [CrossRef]

52. Rudnik-Schoneborn, S.; Heller, R.; Berg, C.; Betzler, C.; Grimm, T.; Eggermann, T.; Eggermann, K.; Wirth, R.; Wirth, B.; Zerres, K. Congenital Heart Disease Is a Feature of Severe Infantile Spinal Muscular Atrophy. J. Med Genet. 2008, 45, 635-638. [CrossRef] [PubMed]

53. Grotto, S.; Cuisset, J.-M.; Marret, S.; Drunat, S.; Faure, P.; Audebert-Bellanger, S.; Desguerre, I.; Flurin, V.; Grebille, A.-G.; Guerrot, A.-M.; et al. Type 0 Spinal Muscular Atrophy: Further Delineation of Prenatal and Postnatal Features in 16 Patients. J. Neuromuscul. Dis. 2016, 3, 487-495. [CrossRef] [PubMed]

54. Menke, L.A.; Poll-The, B.T.; Clur, S.-A.; Bilardo, C.M.; van der Wal, A.C.; Lemmink, H.H.; Cobben, J.M. Congenital Heart Defects in Spinal Muscular Atrophy Type I: A Clinical Report of Two Siblings and a Review of the Literature. Am. J. Med Genet. Part A 2008, 146A, 740-744. [CrossRef] [PubMed]

55. Zerres, K. Natural History in Proximal Spinal Muscular Atrophy. Arch. Neurol. 1995, 52, 518. [CrossRef] [PubMed]

56. Butchbach, M.E.R. Copy Number Variations in the Survival Motor Neuron Genes: Implications for Spinal Muscular Atrophy and Other Neurodegenerative Diseases. Front. Mol. Biosci. 2016, 3. [CrossRef] [PubMed]

57. Zerres, K.; Davies, K.E. 59th ENMC International Workshop: Spinal Muscular Atrophies: Recent Progress and Revised Diagnostic Criteria 17-19 April 1998, Soestduinen, The Netherlands. Neuromuscul. Disord. 1999, 9, 272-278. [CrossRef] 
58. O'Hagen, J.M.; Glanzman, A.M.; McDermott, M.P.; Ryan, P.A.; Flickinger, J.; Quigley, J.; Riley, S.; Sanborn, E.; Irvine, C.; Martens, W.B.; et al. An Expanded Version of the Hammersmith Functional Motor Scale for SMA II and III Patients. Neuromuscul. Disord. 2007, 17, 693-697. [CrossRef] [PubMed]

59. Thomas, N.H.; Dubowitz, V. The Natural History of Type I (Severe) Spinal Muscular Atrophy. Neuromuscul. Disord. 1994, 4, 497-502. [CrossRef]

60. Dawood, A.A.; Moosa, A. Hand and ECG Tremor in Spinal Muscular Atrophy. Arch. Dis. Child. 1983, 58, 376-378. [CrossRef]

61. Sharawat, I.K.; Kohli, T.S.; Saini, L. Trembling Hands and Trembling ECG. BMJ Case Rep. 2019, 12, 230618. [CrossRef] [PubMed]

62. Shorrock, H.K.; Gillingwater, T.H.; Groen, E.J.N. Overview of Current Drugs and Molecules in Development for Spinal Muscular Atrophy Therapy. Drugs 2018, 78, 293-305. [CrossRef] [PubMed]

63. Moosa, A.; Dubowitz, V. Spinal Muscular Atrophy in Childhood: Two Clues to Clinical Diagnosis. Arch. Dis. Child. 1973, 48, 386-388. [CrossRef] [PubMed]

64. Piepers, S.; Berg, L.H.; Brugman, F.; Scheffer, H.; Ruiterkamp-Versteeg, M.; Engelen, B.G.; Faber, C.G.; Visser, M.; Pol, W.-L.; Wokke, J.H.J. A Natural History Study of Late Onset Spinal Muscular Atrophy Types 3b and 4. J. Neurol. 2008, 255, 1400-1404. [CrossRef] [PubMed]

65. Melki, J.; Lefebvre, S.; Burglen, L.; Burlet, P.; Clermont, O.; Millasseau, P.; Reboullet, S.; Benichou, B.; Zeviani, M.; Le Paslier, D.; et al. De Novo and Inherited Deletions of the 5q13 Region in Spinal Muscular Atrophies. Science 1994, 264, $1474-1477$. [CrossRef] [PubMed]

66. Oskoui, M.; Darras, B.T.; De Vivo, D.C. Spinal Muscular Atrophy. In Spinal Muscular Atrophy; Elsevier: Amsterdam, The Netherlands, 2017; pp. 3-19. [CrossRef]

67. Battaglia, G.; Princivalle, A.; Forti, F.; Lizier, C.; Zeviani, M. Expression of the SMN Gene, the Spinal Muscular Atrophy Determining Gene, in the Mammalian Central Nervous System. Hum. Mol. Genet. 1997, 6, 1961-1971. [CrossRef]

68. Renvoise, B. Distinct Domains of the Spinal Muscular Atrophy Protein SMN Are Required for Targeting to Cajal Bodies in Mammalian Cells. J. Cell Sci. 2006, 119, 680-692. [CrossRef] [PubMed]

69. Chaytow, H.; Huang, Y.-T.; Gillingwater, T.H.; Faller, K.M.E. The Role of Survival Motor Neuron Protein (SMN) in Protein Homeostasis. Cell. Mol. Life Sci. 2018, 75, 3877-3894. [CrossRef]

70. So, B.R.; Zhang, Z.; Dreyfuss, G. The Function of Survival Motor Neuron Complex and Its Role in Spinal Muscular Atrophy Pathogenesis. In Spinal Muscular Atrophy; Elsevier: Amsterdam, The Netherlands, 2017; pp. 99-111. [CrossRef]

71. Singh, R.N.; Howell, M.D.; Ottesen, E.W.; Singh, N.N. Diverse Role of Survival Motor Neuron Protein. Biochim. Biophys. Acta (BBA) Gene Regul. Mech. 2017, 1860, 299-315. [CrossRef]

72. Ogawa, C.; Usui, K.; Aoki, M.; Ito, F.; Itoh, M.; Kai, C.; Kanamori-Katayama, M.; Hayashizaki, Y.; Suzuki, H. Gemin2 Plays an Important Role in Stabilizing the Survival of Motor Neuron Complex. J. Biol. Chem. 2007, 282, 11122-11134. [CrossRef]

73. Young, P.J.; Day, P.M.; Zhou, J.; Androphy, E.J.; Morris, G.E.; Lorson, C.L. A Direct Interaction between the Survival Motor Neuron Protein and P53 and Its Relationship to Spinal Muscular Atrophy. J. Biol. Chem. 2002, 277, 2852-2859. [CrossRef]

74. Ponting, C.P. Tudor Domains in Proteins That Interact with RNA. Trends Biochem. Sci. 1997, 22, 51-52. [CrossRef]

75. Brahms, H.; Meheus, L.; De Brabandere, V.; Fischer, U.; Luhrmann, R. Symmetrical Dimethylation of Arginine Residues in Spliceosomal Sm Protein B/B' and the Sm-like Protein LSm4, and Their Interaction with the SMN Protein. RNA 2001, 7. [CrossRef]

76. Martin, R.; Gupta, K.; Ninan, N.S.; Perry, K.; Van Duyne, G.D. The Survival Motor Neuron Protein Forms Soluble Glycine Zipper Oligomers. Structure 2012, 20, 1929-1939. [CrossRef] [PubMed]

77. Selenko, P.; Sprangers, R.; Stier, G.; Bühler, D.; Fischer, U.; Sattler, M. SMN Tudor Domain Structure and Its Interaction with the Sm Proteins. Nat. Struct. Biol. 2001. [CrossRef]

78. Giesemann, T.; Rathke-Hartlieb, S.; Rothkegel, M.; Bartsch, J.W.; Buchmeier, S.; Jockusch, B.M.; Jockusch, H. A Role for Polyproline Motifs in the Spinal Muscular Atrophy Protein SMN. J. Biol. Chem. 1999, 274, 37908-37914. [CrossRef] [PubMed]

79. Nölle, A.; Zeug, A.; van Bergeijk, J.; Tönges, L.; Gerhard, R.; Brinkmann, H.; Al Rayes, S.; Hensel, N.; Schill, Y.; Apkhazava, D.; et al. The Spinal Muscular Atrophy Disease Protein SMN Is Linked to the Rho-Kinase Pathway via Profilin. Hum. Mol. Genet. 2011, 20, 4865-4878. [CrossRef]

80. Charroux, B.; Pellizzoni, L.; Perkinson, R.A.; Shevchenko, A.; Mann, M.; Dreyfuss, G. Gemin3. J. Cell Biol. 1999, 147, 1181-1194. [CrossRef] [PubMed]

81. Gangwani, L.; Mikrut, M.; Theroux, S.; Sharma, M.; Davis, R.J. Spinal Muscular Atrophy Disrupts the Interaction of ZPR1 with the SMN Protein. Nat. Cell Biol. 2001, 3, 376-383. [CrossRef]

82. Zou, J.; Barahmand-pour, F.; Blackburn, M.L.; Matsui, Y.; Chansky, H.A.; Yang, L. Survival Motor Neuron (SMN) Protein Interacts with Transcription Corepressor MSin3A. J. Biol. Chem. 2004, 279, 14922-14928. [CrossRef]

83. Cho, S.; Dreyfuss, G. A Degron Created by SMN2 Exon 7 Skipping Is a Principal Contributor to Spinal Muscular Atrophy Severity. Genes Dev. 2010, 24, 438-442. [CrossRef]

84. Lorson, M.A.; Lorson, C.L. SMN-Inducing Compounds for the Treatment of Spinal Muscular Atrophy. Future Med. Chem. 2012, 4, 2067-2084. [CrossRef] [PubMed]

85. Fan, L. Survival Motor Neuron (SMN) Protein: Role in Neurite Outgrowth and Neuromuscular Maturation during Neuronal Differentiation and Development. Hum. Mol. Genet. 2002, 11, 1605-1614. [CrossRef] 
86. Martínez-Hernández, R.; Soler-Botija, C.; Also, E.; Alias, L.; Caselles, L.; Gich, I.; Bernal, S.; Tizzano, E.F. The Developmental Pattern of Myotubes in Spinal Muscular Atrophy Indicates Prenatal Delay of Muscle Maturation. J. Neuropathol. Exp. Neurol. 2009, 68, 474-481. [CrossRef] [PubMed]

87. Boyer, J.G.; Bowerman, M.; Kothary, R. The Many Faces of SMN: Deciphering the Function Critical to Spinal Muscular Atrophy Pathogenesis. Future Neurol. 2010, 5, 873-890. [CrossRef]

88. Pruss, R.M.; Giraudon-Paoli, M.; Morozova, S.; Berna, P.; Abitbol, J.-L.; Bordet, T. Drug Discovery and Development for Spinal Muscular Atrophy: Lessons from Screening Approaches and Future Challenges for Clinical Development. Future Med. Chem. 2010, 2, 1429-1440. [CrossRef] [PubMed]

89. Food and Drug Administration. FDA Approves First Drug for Spinal Muscular Atrophy. Mol. Cell. Pharmacol. $2017,15$.

90. Zanetta, C.; Nizzardo, M.; Simone, C.; Monguzzi, E.; Bresolin, N.; Comi, G.P.; Corti, S. Molecular Therapeutic Strategies for Spinal Muscular Atrophies: Current and Future Clinical Trials. Clin. Ther. 2014, 36, 128-140. [CrossRef] [PubMed]

91. Hua, Y.; Sahashi, K.; Hung, G.; Rigo, F.; Passini, M.A.; Bennett, C.F.; Krainer, A.R. Antisense Correction of SMN2 Splicing in the CNS Rescues Necrosis in a Type III SMA Mouse Model. Genes Dev. 2010, 24, 1634-1644. [CrossRef]

92. Hua, Y.; Vickers, T.A.; Okunola, H.L.; Bennett, C.F.; Krainer, A.R. Antisense Masking of an HnRNP A1/A2 Intronic Splicing Silencer Corrects SMN2 Splicing in Transgenic Mice. Am. J. Hum. Genet. 2008, 82, 834-848. [CrossRef]

93. Porensky, P.N.; Burghes, A.H.M. Antisense Oligonucleotides for the Treatment of Spinal Muscular Atrophy. Hum. Gene Ther. 2013, 24, 489-498. [CrossRef]

94. Passini, M.A.; Bu, J.; Richards, A.M.; Kinnecom, C.; Sardi, S.P.; Stanek, L.M.; Hua, Y.; Rigo, F.; Matson, J.; Hung, G.; et al. Antisense Oligonucleotides Delivered to the Mouse CNS Ameliorate Symptoms of Severe Spinal Muscular Atrophy. Sci. Transl. Med. 2011, 3, 72ra18. [CrossRef]

95. Geary, R.S.; Norris, D.; Yu, R.; Bennett, C.F. Pharmacokinetics, Biodistribution and Cell Uptake of Antisense Oligonucleotides. Adv. Drug Deliv. Rev. 2015, 87, 46-51. [CrossRef]

96. Dodou, K. Intrathecal Route of Drug Delivery Can Save Lives or Improve Quality of Life. Pharm. J. 2012, $289,501$.

97. Chiriboga, C.A. Nusinersen for the Treatment of Spinal Muscular Atrophy. Expert Rev. Neurother. 2017, 17, 955-962. [CrossRef] [PubMed]

98. Hoy, S.M. Nusinersen: First Global Approval. Drugs 2017, 77, 473-479. [CrossRef] [PubMed]

99. Food and Drug Administration. FDA Approves Innovative Gene Therapy to Treat Pediatric Patients with Spinal Muscular Atrophy, a Rare Disease and Leading Genetic Cause of Infant Mortality. Available online: https://www.fda.gov/news-events / press-announcements/fda-approves-innovative-gene-therapy-treat-pediatric-patients-spinal-muscular-atrophy-rare-disease (accessed on 29 March 2020). [CrossRef]

100. Hensel, N.; Kubinski, S.; Claus, P. The Need for SMN-Independent Treatments of Spinal Muscular Atrophy (SMA) to Complement SMN-Enhancing Drugs. Front. Neurol. 2020, 11. [CrossRef] [PubMed]

101. (Hoy, S.M. Onasemnogene Abeparvovec: First Global Approval. Drugs 2019, 79, 1255-1262. [CrossRef] [PubMed]

102. Mendell, J.R.; Al-Zaidy, S.; Shell, R.; Arnold, W.D.; Rodino-Klapac, L.R.; Prior, T.W.; Lowes, L.; Alfano, L.; Berry, K.; Church, K.; et al. Single-Dose Gene-Replacement Therapy for Spinal Muscular Atrophy. N. Engl. J. Med. 2017, 377, 1713-1722. [CrossRef]

103. Food and Drug Administration. FDA Approves Oral Treatment for Spinal Muscular Atrophy. Available online: https://www.fda. gov/news-events/press-announcements/fda-approves-oral-treatment-spinal-muscular-atrophy (accessed on 28 August 2020).

104. Ratni, H.; Ebeling, M.; Baird, J.; Bendels, S.; Bylund, J.; Chen, K.S.; Denk, N.; Feng, Z.; Green, L.; Guerard, M.; et al. Discovery of Risdiplam, a Selective Survival of Motor Neuron-2 (SMN2) Gene Splicing Modifier for the Treatment of Spinal Muscular Atrophy (SMA). J. Med. Chem. 2018, 61, 6501-6517. [CrossRef]

105. Song, J.Y.; Kim, H.S.; Park, S.-J.; Lee, J.; Lee, J. Nusinersen Administration in Spinal Muscular Atrophy Patients with Severe Scoliosis: Interlaminar Approaches at the Lumbar Level. Ann. Child Neurol. 2020, 28, 49-56. [CrossRef]

106. Zuluaga-Sanchez, S.; Teynor, M.; Knight, C.; Thompson, R.; Lundqvist, T.; Ekelund, M.; Forsmark, A.; Vickers, A.D.; Lloyd, A. Cost Effectiveness of Nusinersen in the Treatment of Patients with Infantile-Onset and Later-Onset Spinal Muscular Atrophy in Sweden. PharmacoEconomics 2019, 37, 845-865. [CrossRef]

107. SMA News Today. Zolgensma. Available online: https://smanewstoday.com/avxs-101-avexis (accessed on 1 April 2020).

108. Roche. FDA Approves Roche's Evrysdi (Risdiplam) for Treatment of Spinal Muscular Atrophy (SMA) in Adults and Children 2 Months and Older. Available online: https://www.roche.com/investors/updates/inv-update-2020-08-10b.htm (accessed on 28 August 2020).

109. Palacino, J.; Swalley, S.E.; Song, C.; Cheung, A.K.; Shu, L.; Zhang, X.; Van Hoosear, M.; Shin, Y.; Chin, D.N.; Keller, C.G.; et al. SMN2 Splice Modulators Enhance U1-Pre-MRNA Association and Rescue SMA Mice. Nat. Chem. Biol. 2015, 11, 511-517. [CrossRef]

110. Hensel, N.; Claus, P. The Actin Cytoskeleton in SMA and ALS: How Does It Contribute to Motoneuron Degeneration? Neuroscientist 2018, 24, 54-72. [CrossRef] [PubMed]

111. Parente, V.; Corti, S. Advances in Spinal Muscular Atrophy Therapeutics. Ther. Adv. Neurol. Disord. 2018, 11, 175628561875450. [CrossRef]

112. Calder, A.N.; Androphy, E.J.; Hodgetts, K.J. Small Molecules in Development for the Treatment of Spinal Muscular Atrophy. J. Med. Chem. 2016, 59, 10067-10083. [CrossRef] [PubMed] 
113. Andrews, J.A.; Miller, T.M.; Vijayakumar, V.; Stoltz, R.; James, J.K.; Meng, L.; Wolff, A.A.; Malik, F.I. CK-2127107 Amplifies Skeletal Muscle Response to Nerve Activation in Humans. Muscle Nerve 2018, 57, 729-734. [CrossRef]

114. Long, K.K.; O'Shea, K.M.; Khairallah, R.J.; Howell, K.; Paushkin, S.; Chen, K.S.; Cote, S.M.; Webster, M.T.; Stains, J.P.; Treece, E.; et al. Specific Inhibition of Myostatin Activation Is Beneficial in Mouse Models of SMA Therapy. Hum. Mol. Genet. 2019, 28, 1076-1089. [CrossRef] [PubMed]

115. Duelen, R.; Corvelyn, M.; Tortorella, I.; Leonardi, L.; Chai, Y.C.; Sampaolesi, M. Medicinal Biotechnology for Disease Modeling, Clinical Therapy, and Drug Discovery and Development. In Introduction to Biotech Entrepreneurship: From Idea to Business; Springer International Publishing: Cham, Switzerland, 2019; pp. 89-128. [CrossRef]

116. Prieto-Martínez, F.D.; López-López, E.; Eurídice Juárez-Mercado, K.; Medina-Franco, J.L. Computational Drug Design MethodsCurrent and Future Perspectives. In Silico Drug Design; Elsevier: Amsterdam, The Netherlands, 2019; pp. 19-44. [CrossRef]

117. Danon, J.J.; Reekie, T.A.; Kassiou, M. Challenges and Opportunities in Central Nervous System Drug Discovery. Trends Chem. 2019, 1, 612-624. [CrossRef]

118. Bagchi, S.; Chhibber, T.; Lahooti, B.; Verma, A.; Borse, V.; Jayant, R.D. In-Vitro Blood-Brain Barrier Models for Drug Screening and Permeation Studies: An Overview. Drug Des. Dev. Ther. 2019, 13, 3591-3605. [CrossRef]

119. Sun, W.; Zheng, W.; Simeonov, A. Drug Discovery and Development for Rare Genetic Disorders. Am. J. Med Genet. Part A 2017, 173, 2307-2322. [CrossRef]

120. Hoolachan, J.M.; Sutton, E.R.; Bowerman, M. Teaching an Old Drug New Tricks: Repositioning Strategies for Spinal Muscular Atrophy. Future Neurol. 2019, 14, FNL25. [CrossRef]

121. Ashburn, T.T.; Thor, K.B. Drug Repositioning: Identifying and Developing New Uses for Existing Drugs. Nat. Rev. Drug Discov. 2004, 3, 673-683. [CrossRef] [PubMed]

122. Chang, J.-G.; Hsieh-Li, H.-M.; Jong, Y.-J.; Wang, N.M.; Tsai, C.-H.; Li, H. Treatment of Spinal Muscular Atrophy by Sodium Butyrate. Proc. Natl. Acad. Sci. USA 2001, 98, 9808-9813. [CrossRef]

123. Andreassi, C.; Angelozzi, C.; Tiziano, F.D.; Vitali, T.; De Vincenzi, E.; Boninsegna, A.; Villanova, M.; Bertini, E.; Pini, A.; Neri, G.; et al. Phenylbutyrate Increases SMN Expression in Vitro: Relevance for Treatment of Spinal Muscular Atrophy. Eur. J. Hum. Genet. 2004, 12, 59-65. [CrossRef] [PubMed]

124. Brahe, C.; Vitali, T.; Tiziano, F.D.; Angelozzi, C.; Pinto, A.M.; Borgo, F.; Moscato, U.; Bertini, E.; Mercuri, E.; Neri, G. Phenylbutyrate Increases SMN Gene Expression in Spinal Muscular Atrophy Patients. Eur. J. Hum. Genet. 2005, 13, 256-259. [CrossRef]

125. Brichta, L. Valproic Acid Increases the SMN2 Protein Level: A Well-Known Drug as a Potential Therapy for Spinal Muscular Atrophy. Hum. Mol. Genet. 2003, 12, 2481-2489. [CrossRef]

126. Minucci, S.; Pelicci, P.G. Histone Deacetylase Inhibitors and the Promise of Epigenetic (and More) Treatments for Cancer. Nat. Rev. Cancer 2006, 6, 38-51. [CrossRef]

127. Sumner, C.J.; Huynh, T.N.; Markowitz, J.A.; Perhac, J.S.; Hill, B.; Coovert, D.D.; Schussler, K.; Chen, X.; Jarecki, J.; Burghes, A.H.M.; et al. Valproic Acid Increases SMN Levels in Spinal Muscular Atrophy Patient Cells. Ann. Neurol. 2003, 54, 647-654. [CrossRef] [PubMed]

128. Pagliarini, V.; Guerra, M.; Di Rosa, V.; Compagnucci, C.; Sette, C. Combined Treatment with the Histone Deacetylase Inhibitor LBH589 and a Splice-switch Antisense Oligonucleotide Enhances SMN2 Splicing and SMN Expression in Spinal Muscular Atrophy Cells. J. Neurochem. 2020, 153, 264-275. [CrossRef] [PubMed]

129. Milane, A.; Fernandez, C.; Vautier, S.; Bensimon, G.; Meininger, V.; Farinotti, R. Minocycline and Riluzole Brain Disposition: Interactions with p-Glycoprotein at the Blood-Brain Barrier. J. Neurochem. 2007, 103, 164-173. [CrossRef] [PubMed]

130. Sohraby, F.; Bagheri, M.; Aryapour, H. Performing an In Silico Repurposing of Existing Drugs by Combining Virtual Screening and Molecular Dynamics Simulation. Methods Mol. Biol. 2019, 1903, 23-43. [CrossRef]

131. Jin, G.; Wong, S.T.C. Toward Better Drug Repositioning: Prioritizing and Integrating Existing Methods into Efficient Pipelines. Drug Discov. Today 2014, 19, 637-644. [CrossRef]

132. Liu, T.; Lin, Y.; Wen, X.; Jorissen, R.N.; Gilson, M.K. BindingDB: A Web-Accessible Database of Experimentally Determined Protein-Ligand Binding Affinities. Nucleic Acids Res. 2007. [CrossRef] [PubMed]

133. Gilson, M.K.; Liu, T.; Baitaluk, M.; Nicola, G.; Hwang, L.; Chong, J. BindingDB in 2015: A Public Database for Medicinal Chemistry, Computational Chemistry and Systems Pharmacology. Nucleic Acids Res. 2016. [CrossRef] [PubMed]

134. Stark, C. BioGRID: A General Repository for Interaction Datasets. Nucleic Acids Res. 2006, 34, D535-D539. [CrossRef]

135. Oughtred, R.; Rust, J.; Chang, C.; Breitkreutz, B.; Stark, C.; Willems, A.; Boucher, L.; Leung, G.; Kolas, N.; Zhang, F.; et al. The BioGRID Database: A Comprehensive Biomedical Resource of Curated Protein, Genetic, and Chemical Interactions. Protein Sci. 2020, 30, 187-200. [CrossRef] [PubMed]

136. Davies, M.; Nowotka, M.; Papadatos, G.; Dedman, N.; Gaulton, A.; Atkinson, F.; Bellis, L.; Overington, J.P. ChEMBL Web Services: Streamlining Access to Drug Discovery Data and Utilities. Nucleic Acids Res. 2015, 43, W612-W620. [CrossRef] [PubMed]

137. Mendez, D.; Gaulton, A.; Bento, A.P.; Chambers, J.; De Veij, M.; Félix, E.; Magariños, M.P.; Mosquera, J.F.; Mutowo, P.; Nowotka, M.; et al. ChEMBL: Towards Direct Deposition of Bioassay Data. Nucleic Acids Res. 2019, 47, D930-D940. [CrossRef]

138. Chen, J.H.; Linstead, E.; Swamidass, S.J.; Wang, D.; Baldi, P. ChemDB Update-Full-Text Search and Virtual Chemical Space. Bioinformatics 2007, 23, 2348-2351. [CrossRef]

139. Pence, H.E.; Williams, A. ChemSpider: An Online Chemical Information Resource. J. Chem. Educ. 2010, 87, 1123-1124. [CrossRef]

140. Lamb, J. The Connectivity Map: A New Tool for Biomedical Research. Nat. Rev. Cancer 2007, 7, 54-60. [CrossRef] [PubMed] 
141. Lamb, J.; Crawford, E.D.; Peck, D.; Modell, J.W.; Blat, I.C.; Wrobel, M.J.; Lerner, J.; Brunet, J.P.; Subramanian, A.; Ross, K.N.; et al. The Connectivity Map: Using Gene-Expression Signatures to Connect Small Molecules, Genes, and Disease. Science 2006, 313, 1929-1935. [CrossRef]

142. Salwinski, L. The Database of Interacting Proteins: 2004 Update. Nucleic Acids Res. 2004, 32, D449-D451. [CrossRef]

143. Xenarios, I. DIP: The Database of Interacting Proteins. Nucleic Acids Res. 2000, 28, 289-291. [CrossRef]

144. Corsello, S.M.; Bittker, J.A.; Liu, Z.; Gould, J.; McCarren, P.; Hirschman, J.E.; Johnston, S.E.; Vrcic, A.; Wong, B.; Khan, M.; et al. The Drug Repurposing Hub: A next-Generation Drug Library and Information Resource. Nat. Med. 2017, 23, 405-408. [CrossRef] [PubMed]

145. Wishart, D.S.; Feunang, Y.D.; Guo, A.C.; Lo, E.J.; Marcu, A.; Grant, J.R.; Sajed, T.; Johnson, D.; Li, C.; Sayeeda, Z.; et al. DrugBank 5.0: A Major Update to the DrugBank Database for 2018. Nucleic Acids Res. 2018, 46, D1074-D1082. [CrossRef] [PubMed]

146. Avram, S.; Bologa, C.G.; Holmes, J.; Bocci, G.; Wilson, T.B.; Nguyen, D.-T.; Curpan, R.; Halip, L.; Bora, A.; Yang, J.J.; et al. DrugCentral 2021 Supports Drug Discovery and Repositioning. Nucleic Acids Res. 2020. [CrossRef]

147. Sun, J.; Jeliazkova, N.; Chupakhin, V.; Golib-Dzib, J.-F.; Engkvist, O.; Carlsson, L.; Wegner, J.; Ceulemans, H.; Georgiev, I.; Jeliazkov, V.; et al. ExCAPE-DB: An Integrated Large Scale Dataset Facilitating Big Data Analysis in Chemogenomics. J. Cheminformatics 2017, 9, 17. [CrossRef]

148. Fahey, M.E.; Bennett, M.J.; Mahon, C.; Jäger, S.; Pache, L.; Kumar, D.; Shapiro, A.; Rao, K.; Chanda, S.K.; Craik, C.S.; et al. GPS-Prot: A Web-Based Visualization Platform for Integrating Host-Pathogen Interaction Data. BMC Bioinform. 2011. [CrossRef]

149. Peri, S. Development of Human Protein Reference Database as an Initial Platform for Approaching Systems Biology in Humans. Genome Res. 2003, 13, 2363-2371. [CrossRef]

150. Keshava Prasad, T.S.; Goel, R.; Kandasamy, K.; Keerthikumar, S.; Kumar, S.; Mathivanan, S.; Telikicherla, D.; Raju, R.; Shafreen, B.; Venugopal, A.; et al. Human Protein Reference Database-2009 Update. Nucleic Acids Res. 2009. [CrossRef]

151. Stathias, V.; Turner, J.; Koleti, A.; Vidovic, D.; Cooper, D.; Fazel-Najafabadi, M.; Pilarczyk, M.; Terryn, R.; Chung, C.; Umeano, A.; et al. LINCS Data Portal 2.0: Next Generation Access Point for Perturbation-Response Signatures. Nucleic Acids Res. 2020. [CrossRef] [PubMed]

152. Zanzoni, A.; Montecchi-Palazzi, L.; Quondam, M.; Ausiello, G.; Helmer-Citterich, M.; Cesareni, G. MINT: A Molecular INTeraction Database. FEBS Lett. 2002, 513, 135-140. [CrossRef]

153. Licata, L.; Briganti, L.; Peluso, D.; Perfetto, L.; Iannuccelli, M.; Galeota, E.; Sacco, F.; Palma, A.; Nardozza, A.P.; Santonico, E.; et al. MINT, the Molecular Interaction Database: 2012 Update. Nucleic Acids Res. 2012. [CrossRef] [PubMed]

154. Hodis, E.; Prilusky, J.; Sussman, J.L. Proteopedia: A Collaborative, Virtual 3D Web-Resource for Protein and Biomolecule Structure and Function. Biochem. Mol. Biol. Educ. 2010. [CrossRef] [PubMed]

155. Kim, S.; Chen, J.; Cheng, T.; Gindulyte, A.; He, J.; He, S.; Li, Q.; Shoemaker, B.A.; Thiessen, P.A.; Yu, B.; et al. PubChem 2019 Update: Improved Access to Chemical Data. Nucleic Acids Res. 2019, 47, D1102-D1109. [CrossRef] [PubMed]

156. Berman, H.M. The Protein Data Bank. Nucleic Acids Res. 2000, 28, 235-242. [CrossRef]

157. Szklarczyk, D.; Gable, A.L.; Lyon, D.; Junge, A.; Wyder, S.; Huerta-Cepas, J.; Simonovic, M.; Doncheva, N.T.; Morris, J.H.; Bork, P.; et al. STRING V11: Protein-Protein Association Networks with Increased Coverage, Supporting Functional Discovery in Genome-Wide Experimental Datasets. Nucleic Acids Res. 2019. [CrossRef]

158. Novick, P.A.; Ortiz, O.F.; Poelman, J.; Abdulhay, A.Y.; Pande, V.S. SWEETLEAD: An in Silico Database of Approved Drugs, Regulated Chemicals, and Herbal Isolates for Computer-Aided Drug Discovery. PLoS ONE 2013, 8, e79568. [CrossRef]

159. Siramshetty, V.B.; Eckert, O.A.; Gohlke, B.O.; Goede, A.; Chen, Q.; Devarakonda, P.; Preissner, S.; Preissner, R. SuperDRUG2: A One Stop Resource for Approved/Marketed Drugs. Nucleic Acids Res. 2018. [CrossRef]

160. Huang, R.; Southall, N.; Wang, Y.; Yasgar, A.; Shinn, P.; Jadhav, A.; Nguyen, D.-T.; Austin, C.P. The NCGC Pharmaceutical Collection: A Comprehensive Resource of Clinically Approved Drugs Enabling Repurposing and Chemical Genomics. Sci. Transl. Med. 2011, 3, 80ps16. [CrossRef]

161. The UniProt Consortium. UniProt: A Worldwide Hub of Protein Knowledge. Nucleic Acids Res. 2019, 47, D506-D515. [CrossRef]

162. Sterling, T.; Irwin, J.J. ZINC 15-Ligand Discovery for Everyone. J. Chem. Inf. Modeling 2015, 55, 2324-2337. [CrossRef]

163. Kanehisa, M. KEGG: Kyoto Encyclopedia of Genes and Genomes. Nucleic Acids Res. 2000, 28, 27-30. [CrossRef]

164. Kanehisa, M.; Furumichi, M.; Tanabe, M.; Sato, Y.; Morishima, K. KEGG: New Perspectives on Genomes, Pathways, Diseases and Drugs. Nucleic Acids Res. 2017, 45, D353-D361. [CrossRef]

165. Iorio, F.; Bosotti, R.; Scacheri, E.; Belcastro, V.; Mithbaokar, P.; Ferriero, R.; Murino, L.; Tagliaferri, R.; Brunetti-Pierri, N.; Isacchi, A.; et al. Discovery of Drug Mode of Action and Drug Repositioning from Transcriptional Responses. Proc. Natl. Acad. Sci. USA 2010, 107, 14621-14626. [CrossRef]

166. Carrella, D.; Napolitano, F.; Rispoli, R.; Miglietta, M.; Carissimo, A.; Cutillo, L.; Sirci, F.; Gregoretti, F.; Di Bernardo, D. Mantra 2.0: An Online Collaborative Resource for Drug Mode of Action and Repurposing by Network Analysis. Bioinformatics 2014 30, 1787-1788. [CrossRef] [PubMed]

167. Cerami, E.G.; Gross, B.E.; Demir, E.; Rodchenkov, I.; Babur, O.; Anwar, N.; Schultz, N.; Bader, G.D.; Sander, C. Pathway Commons, a Web Resource for Biological Pathway Data. Nucleic Acids Res. 2011, 39, D685-D690. [CrossRef] [PubMed]

168. Rodchenkov, I.; Babur, O.; Luna, A.; Aksoy, B.A.; Wong, J.V.; Fong, D.; Franz, M.; Siper, M.C.; Cheung, M.; Wrana, M.; et al. Pathway Commons 2019 Update: Integration, Analysis and Exploration of Pathway Data. Nucleic Acids Res. 2019. [CrossRef] 
169. Fabregat, A.; Sidiropoulos, K.; Viteri, G.; Forner, O.; Marin-Garcia, P.; Arnau, V.; D’Eustachio, P.; Stein, L.; Hermjakob, H. Reactome Pathway Analysis: A High-Performance in-Memory Approach. BMC Bioinform. 2017, 18, 142. [CrossRef] [PubMed]

170. Athar, A.; Füllgrabe, A.; George, N.; Iqbal, H.; Huerta, L.; Ali, A.; Snow, C.; Fonseca, N.A.; Petryszak, R.; Papatheodorou, I.; et al. ArrayExpress Update-From Bulk to Single-Cell Expression Data. Nucleic Acids Res. 2018, 47, D711-D715. [CrossRef]

171. Benson, D.A.; Cavanaugh, M.; Clark, K.; Karsch-Mizrachi, I.; Lipman, D.J.; Ostell, J.; Sayers, E.W. GenBank. Nucleic Acids Res. 2012, 41, D36-D42. [CrossRef]

172. Barrett, T.; Edgar, R. Gene Expression Omnibus: Microarray Data Storage, Submission, Retrieval, and Analysis. Methods Enzymol. 2006, 411, 352-369. [CrossRef] [PubMed]

173. Gaedigk, A.; Ingelman-Sundberg, M.; Miller, N.A.; Leeder, J.S.; Whirl-Carrillo, M.; Klein, T.E. The Pharmacogene Variation (PharmVar) Consortium: Incorporation of the Human Cytochrome P450 (CYP) Allele Nomenclature Database. Clin. Pharmacol. Ther. 2018. [CrossRef] [PubMed]

174. Leinonen, R.; Sugawara, H.; Shumway, M. The Sequence Read Archive. Nucleic Acids Res. 2011, 39, D19-D21. [CrossRef]

175. Smigielski, E.M. DbSNP: A Database of Single Nucleotide Polymorphisms. Nucleic Acids Res. 2000, 28, 352-355. [CrossRef] [PubMed]

176. Mattingly, C.J.; Colby, G.T.; Forrest, J.N.; Boyer, J.L. The Comparative Toxicogenomics Database (CTD). Environ. Health Perspect. 2003. [CrossRef]

177. Piñero, J.; Bravo, À.; Queralt-Rosinach, N.; Gutiérrez-Sacristán, A.; Deu-Pons, J.; Centeno, E.; García-García, J.; Sanz, F.; Furlong, L.I. DisGeNET: A Comprehensive Platform Integrating Information on Human Disease-Associated Genes and Variants. Nucleic Acids Res. 2017, 45, D833-D839. [CrossRef] [PubMed]

178. Visscher, P.M.; Wray, N.R.; Zhang, Q.; Sklar, P.; McCarthy, M.I.; Brown, M.A.; Yang, J. 10 Years of GWAS Discovery: Biology, Function, and Translation. Am. J. Hum. Genet. 2017, 101, 5-22. [CrossRef]

179. Fang, H.; Su, Z.; Wang, Y.; Miller, A.; Liu, Z.; Howard, P.C.; Tong, W.; Lin, S.M. Exploring the FDA Adverse Event Reporting System to Generate Hypotheses for Monitoring of Disease Characteristics. Clin. Pharmacol. Ther. 2014, 95, 496-498. [CrossRef]

180. Hamosh, A. Online Mendelian Inheritance in Man (OMIM), a Knowledgebase of Human Genes and Genetic Disorders. Nucleic Acids Res. 2004, 33, D514-D517. [CrossRef]

181. Carvalho-Silva, D.; Pierleoni, A.; Pignatelli, M.; Ong, C.; Fumis, L.; Karamanis, N.; Carmona, M.; Faulconbridge, A.; Hercules, A.; McAuley, E.; et al. Open Targets Platform: New Developments and Updates Two Years On. Nucleic Acids Res. 2019, 47, D1056-D1065. [CrossRef]

182. Whirl-Carrillo, M.; McDonagh, E.M.; Hebert, J.M.; Gong, L.; Sangkuhl, K.; Thorn, C.F.; Altman, R.B.; Klein, T.E. Pharmacogenomics Knowledge for Personalized Medicine. Clin. Pharmacol. Ther. 2012, 92, 414-417. [CrossRef]

183. Kuhn, M.; Letunic, I.; Jensen, L.J.; Bork, P. The SIDER Database of Drugs and Side Effects. Nucleic Acids Res. 2016, 44, D1075-D1079. [CrossRef]

184. Wang, Y.; Zhang, S.; Li, F.; Zhou, Y.; Zhang, Y.; Wang, Z.; Zhang, R.; Zhu, J.; Ren, Y.; Tan, Y.; et al. Therapeutic Target Database 2020: Enriched Resource for Facilitating Research and Early Development of Targeted Therapeutics. Nucleic Acids Res. 2020, 48, D1031-D1041. [CrossRef]

185. Jia, J.; An, Z.; Ming, Y.; Guo, Y.; Li, W.; Liang, Y.; Guo, D.; Li, X.; Tai, J.; Chen, G.; et al. ERAM: Encyclopedia of Rare Disease Annotations for Precision Medicine. Nucleic Acids Res. 2018, 46, D937-D943. [CrossRef] [PubMed]

186. Weininger, D. SMILES, a Chemical Language and Information System. 1. Introduction to Methodology and Encoding Rules. J. Chem. Inf. Modeling 1988, 28, 31-36. [CrossRef]

187. Heller, S.R.; McNaught, A.; Pletnev, I.; Stein, S.; Tchekhovskoi, D. InChI, the IUPAC International Chemical Identifier. J. Cheminformatics 2015, 7, 23. [CrossRef] [PubMed]

188. Maggiora, G.; Vogt, M.; Stumpfe, D.; Bajorath, J. Molecular Similarity in Medicinal Chemistry. J. Med. Chem. 2014, 57, 3186-3204. [CrossRef]

189. Hodos, R.A.; Kidd, B.A.; Shameer, K.; Readhead, B.P.; Dudley, J.T. In Silico Methods for Drug Repurposing and Pharmacology. Wiley Interdiscip. Rev. Syst. Biol. Med. 2016, 8, 186-210. [CrossRef]

190. Rognan, D. Chemogenomic Approaches to Rational Drug Design. Br. J. Pharmacol. 2007, 152, 38-52. [CrossRef] [PubMed]

191. Nidhi; Glick, M.; Davies, J.W.; Jenkins, J.L. Prediction of Biological Targets for Compounds Using Multiple-Category Bayesian Models Trained on Chemogenomics Databases. J. Chem. Inf. Modeling 2006, 46, 1124-1133. [CrossRef]

192. Cao, D.-S.; Liang, Y.-Z.; Deng, Z.; Hu, Q.-N.; He, M.; Xu, Q.-S.; Zhou, G.-H.; Zhang, L.-X.; Deng, Z.; Liu, S. Genome-Scale Screening of Drug-Target Associations Relevant to Ki Using a Chemogenomics Approach. PLoS ONE 2013, 8, e57680. [CrossRef] [PubMed]

193. Zhang, W.; Chen, Y.; Liu, F.; Luo, F.; Tian, G.; Li, X. Predicting Potential Drug-Drug Interactions by Integrating Chemical, Biological, Phenotypic and Network Data. BMC Bioinform. 2017, 18, 18. [CrossRef] [PubMed]

194. Yang, L.; Agarwal, P. Systematic Drug Repositioning Based on Clinical Side-Effects. PLoS ONE 2011, 6, e28025. [CrossRef]

195. Bisgin, H.; Liu, Z.; Fang, H.; Kelly, R.; Xu, X.; Tong, W. A Phenome-Guided Drug Repositioning through a Latent Variable Model. BMC Bioinform. 2014, 15, 267. [CrossRef] [PubMed]

196. Ye, H.; Liu, Q.; Wei, J. Construction of Drug Network Based on Side Effects and Its Application for Drug Repositioning. PLoS ONE 2014, 9, e87864. [CrossRef] 
197. Sridhar, D.; Fakhraei, S.; Getoor, L. A Probabilistic Approach for Collective Similarity-Based Drug-Drug Interaction Prediction. Bioinformatics 2016. [CrossRef]

198. GNS, H.S.; GR, S.; Murahari, M.; Krishnamurthy, M. An Update on Drug Repurposing: Re-Written Saga of the Drug's Fate. Biomed. Pharmacother. 2019, 110, 700-716. [CrossRef]

199. Zhang, Y. I-TASSER Server for Protein 3D Structure Prediction. BMC Bioinform. 2008, 9, 40. [CrossRef]

200. Webb, B.; Sali, A. Comparative Protein Structure Modeling Using MODELLER. Curr. Protoc. Bioinform. 2016, 54. [CrossRef] [PubMed]

201. Yang, J.; Anishchenko, I.; Park, H.; Peng, Z.; Ovchinnikov, S.; Baker, D. Improved Protein Structure Prediction Using Predicted Interresidue Orientations. Proc. Natl. Acad. Sci. USA 2020, 117, 1496-1503. [CrossRef] [PubMed]

202. Forli, S.; Huey, R.; Pique, M.E.; Sanner, M.F.; Goodsell, D.S.; Olson, A.J. Computational Protein-Ligand Docking and Virtual Drug Screening with the AutoDock Suite. Nat. Protoc. 2016, 11, 905-919. [CrossRef] [PubMed]

203. Trott, O.; Olson, A.J. AutoDock Vina: Improving the Speed and Accuracy of Docking with a New Scoring Function, Efficient Optimization, and Multithreading. J. Comput. Chem. 2009, 31, 455-461. [CrossRef] [PubMed]

204. Van Zundert, G.C.P.; Rodrigues, J.P.G.L.M.; Trellet, M.; Schmitz, C.; Kastritis, P.L.; Karaca, E.; Melquiond, A.S.J.; van Dijk, M.; de Vries, S.J.; Bonvin, A.M.J.J. The HADDOCK2.2 Web Server: User-Friendly Integrative Modeling of Biomolecular Complexes. J. Mol. Biol. 2016, 428, 720-725. [CrossRef]

205. Schneidman-Duhovny, D.; Inbar, Y.; Polak, V.; Shatsky, M.; Halperin, I.; Benyamini, H.; Barzilai, A.; Dror, O.; Haspel, N.; Nussinov, R.; et al. Taking Geometry to Its Edge: Fast Unbound Rigid (and Hinge-Bent) Docking. Proteins Struct. Funct. Genet. 2003, 52, 107-112. [CrossRef]

206. Chen, Y.Z.; Zhi, D.G. Ligand-Protein Inverse Docking and Its Potential Use in the Computer Search of Protein Targets of a Small Molecule. Proteins Struct. Funct. Genet. 2001, 43, 217-226. [CrossRef]

207. Wolber, G.; Langer, T. LigandScout: 3-D Pharmacophores Derived from Protein-Bound Ligands and Their Use as Virtual Screening Filters. J. Chem. Inf. Modeling 2005. [CrossRef]

208. Liu, X.; Ouyang, S.; Yu, B.; Liu, Y.; Huang, K.; Gong, J.; Zheng, S.; Li, Z.; Li, H.; Jiang, H. PharmMapper Server: A Web Server for Potential Drug Target Identification Using Pharmacophore Mapping Approach. Nucleic Acids Res. 2010, 38 (Suppl. S2), W609-W614. [CrossRef]

209. Wang, X.; Shen, Y.; Wang, S.; Li, S.; Zhang, W.; Liu, X.; Lai, L.; Pei, J.; Li, H. PharmMapper 2017 Update: A Web Server for Potential Drug Target Identification with a Comprehensive Target Pharmacophore Database. Nucleic Acids Res. 2017, 45, W356-W360. [CrossRef]

210. Koes, D.R.; Camacho, C.J. ZINCPharmer: Pharmacophore Search of the ZINC Database. Nucleic Acids Res. 2012, 40, W409-W414. [CrossRef] [PubMed]

211. Backman, T.W.H.; Cao, Y.; Girke, T. ChemMine Tools: An Online Service for Analyzing and Clustering Small Molecules. Nucleic Acids Res. 2011, 39, W486-W491. [CrossRef] [PubMed]

212. Lu, J.; Carlson, H.A. ChemTreeMap: An Interactive Map of Biochemical Similarity in Molecular Datasets. Bioinformatics 2016, 32, 3584-3592. [CrossRef] [PubMed]

213. Ravikumar, B.; Alam, Z.; Peddinti, G.; Aittokallio, T. C-SPADE: A Web-Tool for Interactive Analysis and Visualization of Drug Screening Experiments through Compound-Specific Bioactivity Dendrograms. Nucleic Acids Res. 2017. [CrossRef] [PubMed]

214. Nickel, J.; Gohlke, B.-O.; Erehman, J.; Banerjee, P.; Rong, W.W.; Goede, A.; Dunkel, M.; Preissner, R. SuperPred: Update on Drug Classification and Target Prediction. Nucleic Acids Res. 2014, 42, W26-W31. [CrossRef]

215. Jia, Z.; Liu, Y.; Guan, N.; Bo, X.; Luo, Z.; Barnes, M.R. Cogena, a Novel Tool for Co-Expressed Gene-Set Enrichment Analysis, Applied to Drug Repositioning and Drug Mode of Action Discovery. BMC Genom. 2016, 17, 414. [CrossRef] [PubMed]

216. Brown, A.S.; Kong, S.W.; Kohane, I.S.; Patel, C.J. KsRepo: A Generalized Platform for Computational Drug Repositioning. BMC Bioinform. 2016, 17, 78. [CrossRef] [PubMed]

217. Wu, H.; Huang, J.; Zhong, Y.; Huang, Q. DrugSig: A Resource for Computational Drug Repositioning Utilizing Gene Expression Signatures. PLoS ONE 2017, 12, e0177743. [CrossRef] [PubMed]

218. Luo, H.; Li, M.; Wang, S.; Liu, Q.; Li, Y.; Wang, J. Computational Drug Repositioning Using Low-Rank Matrix Approximation and Randomized Algorithms. Bioinformatics 2018, 34, 1904-1912. [CrossRef]

219. Martínez, V.; Navarro, C.; Cano, C.; Fajardo, W.; Blanco, A. DrugNet: Network-Based Drug-Disease Prioritization by Integrating Heterogeneous Data. Artif. Intell. Med. 2015, 63, 41-49. [CrossRef]

220. Mullen, J.; Cockell, S.J.; Woollard, P.; Wipat, A. An Integrated Data Driven Approach to Drug Repositioning Using Gene-Disease Associations. PLoS ONE 2016, 11, e0155811. [CrossRef] [PubMed]

221. Yu, H.; Choo, S.; Park, J.; Jung, J.; Kang, Y.; Lee, D. Prediction of Drugs Having Opposite Effects on Disease Genes in a Directed Network. BMC Syst. Biol. 2016, 10, S2. [CrossRef]

222. Shannon, P. Cytoscape: A Software Environment for Integrated Models of Biomolecular Interaction Networks. Genome Res. 2003, 13, 2498-2504. [CrossRef]

223. Warde-Farley, D.; Donaldson, S.L.; Comes, O.; Zuberi, K.; Badrawi, R.; Chao, P.; Franz, M.; Grouios, C.; Kazi, F.; Lopes, C.T.; et al. The GeneMANIA Prediction Server: Biological Network Integration for Gene Prioritization and Predicting Gene Function. Nucleic Acids Res. 2010, 38 (Suppl. S2), W214-W220. [CrossRef] [PubMed] 
224. Nikitin, A.; Egorov, S.; Daraselia, N.; Mazo, I. Pathway Studio-the Analysis and Navigation of Molecular Networks. Bioinformatics 2003, 19, 2155-2157. [CrossRef] [PubMed]

225. Demir, E.; Babur, O.; Dogrusoz, U.; Gursoy, A.; Nisanci, G.; Cetin-Atalay, R.; Ozturk, M. PATIKA: An Integrated Visual Environment for Collaborative Construction and Analysis of Cellular Pathways. Bioinformatics 2002, 18, 996-1003. [CrossRef] [PubMed]

226. Hu, Z.; Mellor, J.; Wu, J.; DeLisi, C. VisANT: An Online Visualization and Analysis Tool for Biological Interaction Data. BMC Bioinform. 2004, 5, 17. [CrossRef]

227. Engin, H.; Gursoy, A.; Nussinov, R.; Keskin, O. Network-Based Strategies Can Help Mono- and Poly-Pharmacology Drug Discovery: A Systems Biology View. Curr. Pharm. Des. 2014, 20, 1201-1207. [CrossRef]

228. Fotis, C.; Antoranz, A.; Hatziavramidis, D.; Sakellaropoulos, T.; Alexopoulos, L.G. Network-Based Technologies for Early Drug Discovery. Drug Discov. Today 2018, 23, 626-635. [CrossRef]

229. Sidders, B.; Karlsson, A.; Kitching, L.; Torella, R.; Karila, P.; Phelan, A. Network-Based Drug Discovery: Coupling Network Pharmacology with Phenotypic Screening for Neuronal Excitability. J. Mol. Biol. 2018, 430, 3005-3015. [CrossRef]

230. Borg, R.; Cauchi, R.J. GEMINs: Potential Therapeutic Targets for Spinal Muscular Atrophy? Front. Neurosci. 2014, 8, 1-7. [CrossRef] [PubMed]

231. Thompson, L.W.; Morrison, K.D.; Shirran, S.L.; Groen, E.J.N.; Gillingwater, T.H.; Botting, C.H.; Sleeman, J.E. Neurochondrin Interacts with the SMN Protein Suggesting a Novel Mechanism for Spinal Muscular Atrophy Pathology. J. Cell Sci. 2018. [CrossRef] [PubMed]

232. Curmi, F.; Cauchi, R.J. The Multiple Lives of DEAD-Box RNA Helicase DP103/DDX20/Gemin3. Biochem. Soc. Trans. 2018, 46, 329-341. [CrossRef] [PubMed]

233. Wadman, R.I.; Jansen, M.D.; Curial, C.A.D.; Groen, E.J.N.; Stam, M.; Wijngaarde, C.A.; Medic, J.; Sodaar, P.; van Eijk, K.R.; Huibers, M.M.H.; et al. Analysis of FUS, PFN2, TDP-43, and PLS3 as Potential Disease Severity Modifiers in Spinal Muscular Atrophy. Neurol. Genet. 2020, 6, e386. [CrossRef]

234. Tabei, Y.; Kotera, M.; Sawada, R.; Yamanishi, Y. Network-Based Characterization of Drug-Protein Interaction Signatures with a Space-Efficient Approach. BMC Syst. Biol. 2019, 13, 39. [CrossRef]

235. Hensel, N.; Stockbrügger, I.; Rademacher, S.; Broughton, N.; Brinkmann, H.; Grothe, C.; Claus, P. Bilateral Crosstalk of Rhoand Extracellular-Signal-Regulated-Kinase (ERK) Pathways Is Confined to an Unidirectional Mode in Spinal Muscular Atrophy (SMA). Cell. Signal. 2014, 26, 540-548. [CrossRef]

236. Fu, P.-C.; Tang, R.-H.; Yu, Z.-Y.; Xie, M.-J.; Wang, W.; Luo, X. The Rho-Associated Kinase Inhibitors Y27632 and Fasudil Promote Microglial Migration in the Spinal Cord via the ERK Signaling Pathway. Neural Regen. Res. 2018, 13, 677. [CrossRef]

237. Mack, S.G.; Cook, D.J.; Dhurjati, P.; Butchbach, M.E.R. Systems Biology Investigation of CAMP Modulation to Increase SMN Levels for the Treatment of Spinal Muscular Atrophy. PLoS ONE 2014, 9, 1-26. [CrossRef] [PubMed]

238. Hensel, N.; Ratzka, A.; Brinkmann, H.; Klimaschewski, L.; Grothe, C.; Claus, P. Analysis of the Fibroblast Growth Factor System Reveals Alterations in a Mouse Model of Spinal Muscular Atrophy. PLoS ONE 2012, 7, e31202. [CrossRef]

239. Schellino, R.; Boido, M.; Borsello, T.; Vercelli, A. Pharmacological C-Jun NH2-Terminal Kinase (JNK) Pathway Inhibition Reduces Severity of Spinal Muscular Atrophy Disease in Mice. Front. Mol. Neurosci. 2018, 11. [CrossRef]

240. Simon, C.M.; Dai, Y.; Van Alstyne, M.; Koutsioumpa, C.; Pagiazitis, J.G.; Chalif, J.I.; Wang, X.; Rabinowitz, J.E.; Henderson, C.E.; Pellizzoni, L.; et al. Converging Mechanisms of P53 Activation Drive Motor Neuron Degeneration in Spinal Muscular Atrophy. Cell Rep. 2017, 21, 3767-3780. [CrossRef]

241. Bowerman, M.; Beauvais, A.; Anderson, C.L.; Kothary, R. Rho-Kinase Inactivation Prolongs Survival of an Intermediate SMA Mouse Model. Hum. Mol. Genet. 2010, 19, 1468-1478. [CrossRef]

242. Bowerman, M.; Murray, L.M.; Boyer, J.G.; Anderson, C.L.; Kothary, R. Fasudil Improves Survival and Promotes Skeletal Muscle Development in a Mouse Model of Spinal Muscular Atrophy. BMC Med. 2012, 10, 24. [CrossRef]

243. Demeler, B.; Zhou, G. Neural Network Optimization for E.Coli Promoter Prediction. Nucleic Acids Res. 1991, 19, 1593-1599. [CrossRef] [PubMed]

244. Holley, L.H.; Karplus, M. Protein Secondary Structure Prediction with a Neural Network. Proc. Natl. Acad. Sci. USA 1989, 86, 152-156. [CrossRef] [PubMed]

245. Yang, X.; Wang, Y.; Byrne, R.; Schneider, G.; Yang, S. Concepts of Artificial Intelligence for Computer-Assisted Drug Discovery. Chem. Rev. 2019, 119, 10520-10594. [CrossRef] [PubMed]

246. LeCun, Y.; Bengio, Y.; Hinton, G. Deep Learning. Nature 2015, 521, 436-444. [CrossRef] [PubMed]

247. Gawehn, E.; Hiss, J.A.; Brown, J.B.; Schneider, G. Advancing Drug Discovery via GPU-Based Deep Learning. Expert Opin. Drug Discov. 2018, 13, 579-582. [CrossRef]

248. Li, G.-B.; Yang, L.-L.; Wang, W.-J.; Li, L.-L.; Yang, S.-Y. ID-Score: A New Empirical Scoring Function Based on a Comprehensive Set of Descriptors Related to Protein-Ligand Interactions. J. Chem. Inf. Modeling 2013, 53, 592-600. [CrossRef]

249. Rensi, S.E.; Altman, R.B. Shallow Representation Learning via Kernel PCA Improves QSAR Modelability. J. Chem. Inf. Modeling 2017, 57, 1859-1867. [CrossRef]

250. Hartenfeller, M.; Zettl, H.; Walter, M.; Rupp, M.; Reisen, F.; Proschak, E.; Weggen, S.; Stark, H.; Schneider, G. DOGS: ReactionDriven de Novo Design of Bioactive Compounds. PLoS Comput. Biol. 2012, 8, e1002380. [CrossRef] 
251. Merk, D.; Friedrich, L.; Grisoni, F.; Schneider, G. De Novo Design of Bioactive Small Molecules by Artificial Intelligence. Mol. Inform. 2018, 37, 1700153. [CrossRef]

252. Napolitano, F.; Zhao, Y.; Moreira, V.M.; Tagliaferri, R.; Kere, J.; D’Amato, M.; Greco, D. Drug Repositioning: A Machine-Learning Approach through Data Integration. J. Cheminformatics 2013, 5, 30. [CrossRef]

253. Karlov, D.S.; Sosnin, S.; Tetko, I.V.; Fedorov, M.V. Chemical Space Exploration Guided by Deep Neural Networks. RSC Adv. 2019, 9,5151-5157. [CrossRef]

254. Vamathevan, J.; Clark, D.; Czodrowski, P.; Dunham, I.; Ferran, E.; Lee, G.; Li, B.; Madabhushi, A.; Shah, P.; Spitzer, M.; et al. Applications of Machine Learning in Drug Discovery and Development. Nat. Rev. Drug Discov. 2019, 18, 463-477. [CrossRef] [PubMed]

255. Burki, T. A New Paradigm for Drug Development. Lancet Digit. Health 2020, 2, e226-e227. [CrossRef]

256. The World Federation of Neurology. Platform Communications: Abstract Book-30th International Symposium on ALS/MND. Amyotroph. Lateral Scler. Front. Degener. 2019, 20 (Suppl. S1), 1-99. [CrossRef] [PubMed]

257. Stopford, M.; Myszczynska, M.; Markus, N.; Sheppard, D.; Richardson, P.; Phelan, A.; Mead, R.; Ferraiuolo, L. C29 Harnessing Machine Learning and Artificial Intelligence to Identify Novel ALS Therapeutics. Amyotroph. Lateral Scler. Front. Degener. 2017, 18 (Suppl. S2), 20-21. [CrossRef]

258. Querin, G.; El Mendili, M.-M.; Bede, P.; Delphine, S.; Lenglet, T.; Marchand-Pauvert, V.; Pradat, P.-F. Multimodal Spinal Cord MRI Offers Accurate Diagnostic Classification in ALS. J. Neurol. Neurosurg. Psychiatry 2018, 89, 1220-1221. [CrossRef]

259. D’hulst, L.; Van Weehaeghe, D.; Chiò, A.; Calvo, A.; Moglia, C.; Canosa, A.; Cistaro, A.; Willekens, S.M.; De Vocht, J.; Van Damme, P.; et al. Multicenter Validation of (18 F)-FDG PET and Support-Vector Machine Discriminant Analysis in Automatically Classifying Patients with Amyotrophic Lateral Sclerosis versus Controls. Amyotroph. Lateral Scler. Front. Degener. 2018, 19, 570-577. [CrossRef] [PubMed]

260. Van der Burgh, H.K.; Schmidt, R.; Westeneng, H.-J.; de Reus, M.A.; van den Berg, L.H.; van den Heuvel, M.P. Deep Learning Predictions of Survival Based on MRI in Amyotrophic Lateral Sclerosis. NeuroImage Clin. 2017, 13, 361-369. [CrossRef]

261. Prykhodko, O.; Johansson, S.V.; Kotsias, P.-C.; Arús-Pous, J.; Bjerrum, E.J.; Engkvist, O.; Chen, H. A de Novo Molecular Generation Method Using Latent Vector Based Generative Adversarial Network. J. Cheminformatics 2019, 11, 74. [CrossRef]

262. Kadurin, A.; Nikolenko, S.; Khrabrov, K.; Aliper, A.; Zhavoronkov, A. DruGAN: An Advanced Generative Adversarial Autoencoder Model for de Novo Generation of New Molecules with Desired Molecular Properties in Silico. Mol. Pharm. 2017, 14, 3098-3104. [CrossRef]

263. Popova, M.; Isayev, O.; Tropsha, A. Deep Reinforcement Learning for de Novo Drug Design. Sci. Adv. 2018. [CrossRef] [PubMed]

264. Öztürk, H.; Özgür, A.; Ozkirimli, E. DeepDTA: Deep Drug-Target Binding Affinity Prediction. Bioinformatics 2018, 34, i821-i829. [CrossRef] [PubMed]

265. Zitnik, M.; Agrawal, M.; Leskovec, J. Modeling Polypharmacy Side Effects with Graph Convolutional Networks. Bioinformatics 2018, 34, i457-i466. [CrossRef] [PubMed]

266. Zhang, X.; Xiao, C.; Glass, L.M.; Sun, J. DeepEnroll: Patient-Trial Matching with Deep Embedding and Entailment Prediction. arXiv 2020, arXiv:2001.08179.

267. Ismail, H.M.; Dorchies, O.M.; Scapozza, L. The Potential and Benefits of Repurposing Existing Drugs to Treat Rare Muscular Dystrophies. Expert Opin. Orphan Drugs 2018, 6, 259-271. [CrossRef] 